\title{
Observations of atmospheric mercury in China: a critical review
}

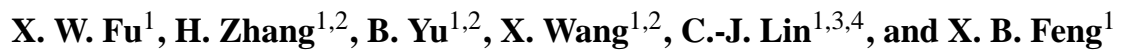 \\ ${ }^{1}$ State Key Laboratory of Environmental Geochemistry, Institute of Geochemistry, Chinese Academy of Sciences, \\ Guiyang 550002, China \\ ${ }^{2}$ University of the Chinese Academy of Sciences, Beijing 100049, China \\ ${ }^{3}$ Department of Civil and Environmental Engineering, Lamar University, Beaumont, Texas 77710, USA \\ ${ }^{4}$ College of Energy and Environment, South China University of Technology, Guangzhou 510006, China
}

Correspondence to: X. B. Feng (fengxinbin@ vip.skleg.cn)

Received: 28 January 2015 - Published in Atmos. Chem. Phys. Discuss.: 22 April 2015

Revised: 11 August 2015 - Accepted: 11 August 2015 - Published: 24 August 2015

\begin{abstract}
China presently contributes the largest amount of anthropogenic mercury $(\mathrm{Hg})$ emission into the atmosphere in the world. Over the past decade, numerous studies have been conducted to characterize the concentration and forms of atmospheric $\mathrm{Hg}$ in China, which provide insights into the spatial and temporal distributions of atmospheric $\mathrm{Hg}$ through ground-based measurements at widely diverse geographical locations and during cruise and flight campaigns. In this paper, we present a comprehensive review of the state of understanding in atmospheric $\mathrm{Hg}$ in China. Gaseous elemental mercury (GEM) and particulate-bound mercury (PBM) measured at the remote sites in China are substantially elevated compared to the background values in the Northern Hemisphere. In Chinese urban areas, the highly elevated GEM, PBM and gaseous oxidized mercury (GOM) were mainly derived from local anthropogenic $\mathrm{Hg}$ emissions, whereas regional anthropogenic emissions and long-range transport from domestic source regions are the primary causes of the elevated GEM and PBM concentrations at remote sites. Using 7-9 years of continuous observations at a remote site and an urban site, a slight increase in atmospheric GEM (2.4$2.5 \% \mathrm{yr}^{-1}$ ) was identified (paired samples test: $p<0.01$ ), which is in agreement with the increasing domestic anthropogenic emissions. Anthropogenic GEM emission quantity in China estimated through the observed GEM / CO concentration ratios ranged from 632 to $1138 \mathrm{t}$ annually over the past decade, 2-3 times larger than published values using emission activity data. Modeling results and filed measurements show dry deposition is the predominant process for removing $\mathrm{Hg}$ from the atmosphere, 2.5-9.0 times larger than wet deposition, due to the elevated atmospheric GEM and
\end{abstract}

PBM concentrations that facilitate dry deposition to terrestrial landscapes. Further studies to reconcile the observed and simulated $\mathrm{Hg}$ concentrations, to understand the impact of domestic emission reduction on $\mathrm{Hg}$ concentration and deposition and to delineate the role of $\mathrm{Hg}$ emission and deposition of China in the global $\mathrm{Hg}$ biogeochemical cycle, are needed.

\section{Introduction}

Mercury $(\mathrm{Hg})$ is a toxic air pollutant that exists in the atmosphere. There are three operationally defined $\mathrm{Hg}$ forms: gaseous elemental mercury (GEM), particulate-bound mercury (PBM), and gaseous oxidized mercury (GOM). The sum of GEM and GOM is known as total gaseous mercury (TGM). Because of its mild reactivity, high volatility, low dry deposition velocity and water solubility, GEM is the most abundant form of $\mathrm{Hg}$ in the atmosphere. GEM has an atmospheric residence time of $0.5-2$ years and can spread globally before being deposited to earth's surfaces (Schroeder and Munthe, 1998). Rapid transformations of GEM to GOM and PBM have been observed in the polar regions, upper free troposphere, lower stratosphere, and marine boundary layer, indicating a much shorter residence time of GEM in these environments (Schroeder et al., 1998; Hedgecock and Pirrone, 2003; Lyman and Jaffe, 2012; Timonen et al., 2013; Murphy et al., 1998). On the other hand, GOM and PBM have much higher dry deposition velocity and water solubility, and can be readily removed from the atmosphere. The persistence of GEM makes $\mathrm{Hg}$ one of the most widely distributed pollutants in the atmosphere. 
Both anthropogenic and natural sources emit GEM into the atmosphere, while anthropogenic sources also emit GOM and PBM (Pirrone et al., 2010; Pacyna et al., 2010). Due to the anthropogenic emission and recycling of deposited mercury, the budget of atmospheric $\mathrm{Hg}$ has been increasing by a factor of 3 since the onset of the industrial revolution (Mason and Sheu, 2002). Over the past 2 decades, advancement in emission control measures has greatly reduced anthropogenic $\mathrm{Hg}$ emissions and led to a decrease in atmospheric TGM concentrations in Europe and North America (Slemr and Scheel, 1998; Slemr et al., 2003; Cole et al., 2013). The global anthropogenic emissions, however, have remained relatively unchanged during the same period, probably caused by the increase in anthropogenic emissions in Asia because of the increasing energy use and lower degree of emission control (AMAP/UNEP, 2013; L. Zhang et al., 2015). China is the world's strongest source region of anthropogenic $\mathrm{Hg}$ emission. The annual anthropogenic $\mathrm{Hg}$ emissions were in the range from 500 to $1000 \mathrm{t}$ (Streets et al., 2005; Wu et al., 2006; Liang et al., 2013), approximately $1 / 3$ of the global anthropogenic emissions. GEM emission fluxes from terrestrial landscapes in China were also found to be significantly higher than those observed in Europe and North America (Fu et al., 2015).

There is a need to assess the source, transport, transformation and deposition of atmospheric $\mathrm{Hg}$ in China, which is critical in understanding the global biogeochemical cycle of $\mathrm{Hg}$. In the past $\sim 15$ years, significant understanding has been obtained regarding atmospheric $\mathrm{Hg}$ studies in China. The knowledge is crucial to resolve the spatial distribution of atmospheric $\mathrm{Hg}$, constrain the $\mathrm{Hg}$ emission inventory, assess $\mathrm{Hg}$ transport, and evaluate the roles of China emissions in the regional- and global-scale $\mathrm{Hg}$ biogeochemical cycles. In our previous study (Fu et al., 2012c), we synthesized the observations of atmospheric $\mathrm{Hg}$ in China before 2011. Over the past 4-5 years, many advances have been achieved in atmospheric $\mathrm{Hg}$ studies in China. In this paper, we comprehensively review the atmospheric $\mathrm{Hg}$ data in China, discuss spatial and temporal distributions and estimate the $\mathrm{Hg}$ emissions in China based on the observations. A new analysis regarding the long-term trend of atmospheric GEM is also presented. The trend helps explain the discrepancy between decreasing atmospheric GEM concentrations in Europe and North America and increasing global anthropogenic emissions. The implications and future research needs for further understanding of atmospheric $\mathrm{Hg}$ in China are also presented.

\section{Observational approaches}

\subsection{Atmospheric total gaseous mercury (TGM) and gaseous elemental mercury (GEM)}

Most TGM and GEM measurements in China were made using the commercial model $2537 \mathrm{~A} / \mathrm{B}$ automated ambient mercury vapor analyzer (Tekran, Canada). This analyzer has a detection limit of $\sim 0.1 \mathrm{ng} \mathrm{m}^{-3}$ as specified by the Tekran Instrument Corporation. There have been debates as to whether Tekran model 2537 measures TGM or only GEM. Under the typical conditions of the marine boundary layer (presence of sea salt aerosols and humid air), GOM is not likely to bypass the sampling line with a soda lime trap and an unheated Teflon sampling tube, and therefore the measurement is GEM (Fu et al., 2010b; Moore et al., 2013). For other instances, the measured atmospheric $\mathrm{Hg}$ vapor likely represents TGM. GEM concentration in China is approximately 2 orders of magnitude higher than GOM concentration. Therefore, the measured TGM concentration is often analytically indistinguishable from GEM concentration given the magnitude of the detection limit. In this review, we refer the atmospheric TGM and GEM observations in China to GEM for clarity and consistency.

The RA-915 + Hg analyzer (Lumex, Russia) has also been used for monitoring of GEM in studies at sites with elevated concentrations (Yang et al., 2009; Ci et al., 2011a, b). This analyzer can measure GEM at a very short interval of $1 \mathrm{~s}$ and has a detection limit from 0.3 to $1.0 \mathrm{ng} \mathrm{m}^{-3}$ (Ci et al., 2011a). Previous studies revealed that the RA-915 $+\mathrm{Hg}$ analyzer has a good agreement with the traditional gold trap/CVAFS (cold-vapor atomic fluorescence spectrometry) method and the Tekran 2537 automated analyzer for GEM measurements in urban areas, with GEM concentrations ranging from 1 to $100 \mathrm{ng} \mathrm{m}^{-3}$ (Kim et al., 2006; Fu et al., 2011b). However, further field intercomparisons are needed for validating the RA-915 + Hg analyzer's performance at remote and/or highaltitude sites. A manual method that collects GEM on goldcoated beads or sand traps followed by thermal desorption and detection of CVAFS has also been used (Fang et al., 2004; Xiang and Liu, 2008), which compares well with automated GEM analyzers (Ebinghaus et al., 1999).

\subsection{Atmospheric gaseous oxidized mercury (GOM) and particulate bounded mercury (PBM)}

There are currently no standard methods for measurements of GOM and PBM due to the unknown chemical composition of GOM and PBM as well as a lack of reliable sampling and calibration techniques. Therefore, the measurements of the two atmospheric $\mathrm{Hg}$ forms (especially GOM) should be regarded as a qualitative indication (Gustin and Jaffe, 2010; Gustin et al., 2015). Several studies utilized the Tekran 2537/1130/1135 automated speciation analyzer system for GOM and PBM measurements (Fu et al., 2011a; 
Zhang et al., 2013; Xu et al., 2015). This system has been described in detail elsewhere (Landis et al., 2002; Lindberg et al., 2002; Lan et al., 2012). Coarse particles with an aerodynamic size of $>2.5 \mu \mathrm{m}$ are firstly removed by a glass inertial impactor inlet prior to entering the system. Therefore, the PBM measured by this system represents $\mathrm{Hg}$ bounded with fine $(<2.5 \mu \mathrm{m})$ particulates. The detection limits of GOM and PBM have been reported to be $0.5-6 \mathrm{pg} \mathrm{m}^{-3}$, depending on sampling duration (Landis et al., 2002; Poissant et al., 2005). There are uncertainties about GOM and PBM measurements using the Tekran system, including a lack of calibration standards for GOM and PBM, incomplete collection and loss of GOM and PBM during sampling (Jaffe et al., 2014; Gustin et al., 2015). Recent field and laboratory intercomparisons suggested that the GOM measured by the Tekran system may be biased low by a factor of 1.6-10.6 times compared to recently developed methods using the Detector for Oxidized Hg Species (DOHGS), nylon membranes and cation exchange membranes, and the magnitude of bias can be influenced by the forms of GOM, ozone and relative humidity (Lyman et al., 2010; Huang et al., 2013; Gustin et al., 2013; Ambrose et al., 2013; McClure et al., 2014).

A manual method similar to the Tekran 2537/1130/1135 system has also been deployed (Fu et al., 2012a; Zhang et al., 2015a). This method collects GOM and PBM onto a KClcoated quartz annular denuder and a quartz fiber filter in sequence. After sampling, the annual denuder and quartz filter (transported manually into a quartz tube) are flushed with zero air, followed by thermal desorption that converts GOM and PBM into GEM for CVAFS detection. The detection limits of GOM and PBM based on 3 times the standard deviations of blanks are 1.2 and $4.2 \mathrm{pg} \mathrm{m}^{-3}$, respectively (Fu et al., 2012a). GOM measurement using the manual method is also subjected to the analytical uncertainties associated with the Tekran automated speciation system. Hence, GOM data presented in this paper probably underestimate ambient GOM concentrations in China.

Total particulate-bounded mercury (TPM) has also been measured in China. In these studies, airborne particles were collected onto a glass and/or quartz fiber filter without any upstream particulate collection devices. Fu et al. (2008b) and $\mathrm{Xu}$ et al. (2013) used a thermal desorption coupled with detection by a Tekran 2537 analyzer and a Lumex RA-915 $+\mathrm{Hg}$ analyzer, while others used acid digestion and CVAFS detection (Fang et al., 2004; Z.W. Wang et al., 2006; Xiu et al., 2009). The thermal desorption method yields relatively lower $(\sim 30 \%)$ values compared to the acid digestion method, likely due to the matrix interferences that reduce the collection efficiency of $\mathrm{Hg}$ onto gold pre-concentration traps (Lynam and Keeler, 2002).

\subsection{Wet deposition}

Wet deposition flux of atmospheric $\mathrm{Hg}$ can be estimated via periodic or event-based measurements of $\mathrm{Hg}$ concentration in rainwater and rainfall depth. Previous studies in China used both a bulk collector (Fu et al., 2008b; Guo et al., 2008; Wan et al., 2009a; Fu et al., 2010a) and a wet-only collector (Fu et al., 2010b; Liu et al., 2011; Wang et al., 2012; Zhu et al., 2014; Zhou et al., 2013). The bulk collector tends to overestimate the wet deposition flux due to the dry deposition of TPM and GOM in the sampling period. Such artifacts may be lowered with a short sampling duration (e.g., $<1$ week) or at remote sites where TPM and GOM concentration is low (Landis and Keeler, 1997). Given that TPM concentrations in China are generally elevated (Sect. 3.1), previous observations using bulk collectors likely overestimated wet deposition fluxes.

\subsection{Atmospheric dry deposition}

Dry deposition is an important removal pathway of atmospheric Hg. Dry deposition velocities for atmospheric $\mathrm{Hg}$ vary significantly with the physical and chemical forms of $\mathrm{Hg}$, meteorological conditions, and surface characteristics (Gustin and Jaffe, 2010). Zhang et al. (2009) reviewed the dry deposition velocities of different atmospheric $\mathrm{Hg}$ forms. Using the measured concentrations of atmospheric $\mathrm{Hg}$ species and modeled dry deposition velocities, Zhang et al. (2012) estimated the speciated and total $\mathrm{Hg}$ dry deposition fluxes in eastern and central North America. The result suggested that dry deposition flux of $\mathrm{Hg}$ is comparable to the wet deposition flux in North America.

Given the levels of GEM, GOM and PBM being highly elevated (more details in Sect. 3.1), dry deposition of $\mathrm{Hg}$ may be more important in China than in North America. Studies of dry deposition flux in China are limited due to the challenges in accurately measuring speciated $\mathrm{Hg}$ concentrations and dry deposition velocities. Modeling approaches have been attempted to estimate dry deposition fluxes (Lin et al., 2010; L. Wang et al., 2014). However, there may exist significant uncertainties in the estimates because the simulated $\mathrm{Hg}$ concentrations are significantly different from the observed concentrations of speciated atmospheric $\mathrm{Hg}$.

Dry deposition flux of $\mathrm{Hg}$ in forest ecosystems in China has also been investigated (Wang et al., 2009; Fu et al., $2010 \mathrm{~b}, \mathrm{a})$. These studies estimated deposition fluxes using data of throughfall and litterfall, which provide a reasonable estimate of total dry deposition in forest ecosystems ( $\mathrm{St}$ Louis et al., 2001; Zhang et al., 2012). However, due to the incomplete understanding of the sources of $\mathrm{Hg}$ in litterfall, air-foliage $\mathrm{Hg}$ exchange and dry deposition to forest soil, these estimates should be considered approximate. 


\section{Results and discussion}

\subsection{Atmospheric Hg observed at ground-based sites}

\subsubsection{GEM concentrations, spatial distribution and its relationship with anthropogenic $\mathrm{Hg}$ emissions}

Table 1 shows the statistical summary of speciated atmospheric $\mathrm{Hg}$ concentrations and associated site information. Averaged GEM concentrations at remote sites were in the range of $1.60-5.07 \mathrm{ng} \mathrm{m}^{-3}$ (mean $=2.86 \pm 0.95 \mathrm{ng} \mathrm{m}^{-3}$, $n=12$ ), generally elevated compared to those observed in North America, Europe, South Africa and South America (Table 1). The mean GEM concentrations at 11 of the 12 remote sites in China exceeded the background concentration of GEM (1.5-1.7 $\mathrm{ng} \mathrm{m}^{-3}$ ) in the Northern Hemisphere (Lindberg et al., 2007). Clear spatial variations of GEM concentrations were observed at the remote sites (Fig. 1). In general, GEM concentrations in northeastern, northwestern, and southwestern China (Mt. Changbai, Mt. Waliguan, and Mt. Ailao, means $=1.60-2.09 \mathrm{ng} \mathrm{m}^{-3}$ ) were lower ( $t$ test, $p<0.01)$ than those $\left(2.31-5.07 \mathrm{ng} \mathrm{m}^{-3}\right)$ in northern, southern, and eastern China (e.g., Chengshantou, Chongming Island, Mt. Leigong, Miyun, Mt. Damei, and Mt. Dinghu). This pattern is similar to the spatial distribution of anthropogenic $\mathrm{Hg}^{0}$ emissions (Fig. 1). Most of the $\mathrm{Hg}$ emission sources in China are located in northern, central, eastern, and southern China. Anthropogenic GEM emissions in northeastern (Jilin and Heilongjiang provinces), western (Xinjiang, Xizang, and Qinghai provinces), and southwestern China (mainly in Yunnan Province) are lower (Fig. 1). The mean GEM concentrations at remote sites increased with the regional GEM emissions surrounding the sampling sites (Fig. 2), suggesting the influence of anthropogenic GEM emissions on the distribution of atmospheric $\mathrm{Hg}$ in remote areas.

Mean GEM concentrations at urban sites ranged from 2.50 to $28.6 \mathrm{ng} \mathrm{m}^{-3}$ (mean $=9.20 \pm 7.56 \mathrm{ng} \mathrm{m}^{-3}, n=13$ ), significantly higher than the GEM concentrations measured at remote sites $(t$ test, $p<0.01)$. In contrast to remote sites, no significant positive correlations were observed between mean GEM concentrations at urban sites and regional GEM emissions surrounding the sampling sites $(p>0.05$ for all correlations between GEM and emissions within $1^{\circ} \times 1^{\circ}$, $3^{\circ} \times 3^{\circ}$ and $5^{\circ} \times 5^{\circ}$ grid cells, Fig. 2). Additionally, the mean GEM concentrations at urban sites were significantly different from that at remote sites $(t$ test, $p<0.01)$, whereas the anthropogenic GEM emissions within $1^{\circ} \times 1^{\circ}(t$ test, $p=0.06), 3^{\circ} \times 3^{\circ}(t$ test, $p=0.11)$, and $5^{\circ} \times 5^{\circ}(t$ test, $p=0.19)$ grid cells surrounding the urban sites and remote sites were not significantly different. We conclude that anthropogenic GEM emissions in the vicinity of the sampling sites play an important role for the highly elevated GEM concentrations at urban sites. Urban areas in China are densely populated and heavily industrialized. The high energy demand and the presence of other large point sources (e.g.,

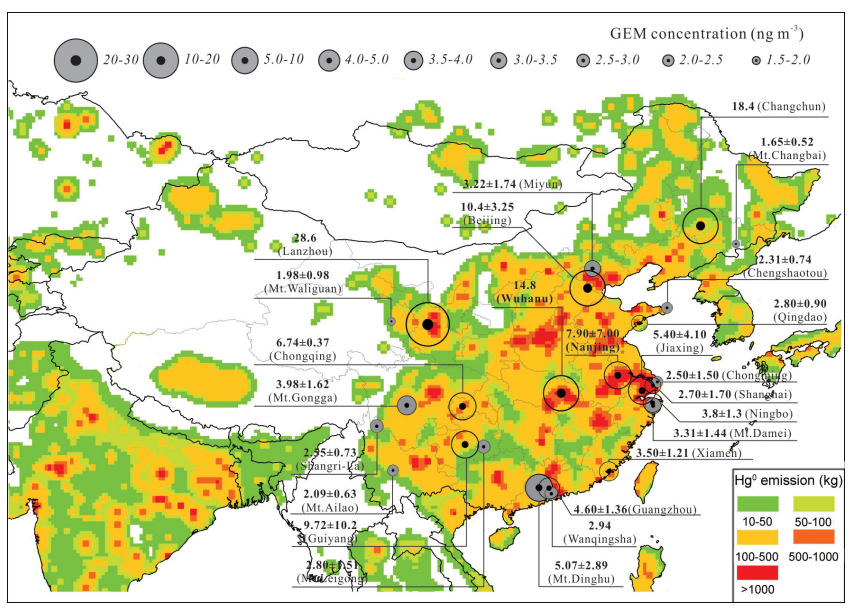

Figure 1. A map showing the locations and atmospheric GEM concentrations observed at ground-based sites in China (gray circles and hollow circles indicate remote and urban sites, respectively. GEM concentrations are indicated by the size of the circles. Data sets were from literatures in Table 1 ) and $0.5^{\circ} \times 0.5^{\circ}$ gridded anthropogenic $\mathrm{Hg}^{0}$ emissions in Asia (AMAP/UNEP, 2013).

iron and steel production, non-ferrous metals smelting, cement production) contribute to the large $\mathrm{Hg}^{0}$ emissions ( $\mathrm{Fu}$ et al., 2011a; Zhu et al., 2012; Chen et al., 2013). For example, the annual anthropogenic $\mathrm{Hg}$ emissions in Guiyang and Nanjing reached $1.75 \mathrm{t}$ and $4.26 \mathrm{t}$, respectively (Zhu et al., 2012; Fu and Feng, 2015). Large emissions of GEM from natural surfaces in the urban areas may also play a role for the elevated GEM concentrations (Feng et al., 2005; D. Y. Wang et al., 2006; Zhu et al., 2012). There is a clear spatial distribution pattern of GEM at urban sites (Fig. 1). The mean GEM concentrations in the six coastal cities including Qingdao, Shanghai, Ningbo, Xiamen, Guangzhou and Jiaxing were in the range of $2.70-5.4 \mathrm{ng} \mathrm{m}^{-3}$, significantly lower ( $t$ test, $p<0.01)$ than that $\left(6.74\right.$ to $\left.28.6 \mathrm{ng} \mathrm{m}^{-3}\right)$ in other inland cities, probably caused by the influence of clean marine air.

\subsubsection{TPM and PBM concentrations}

TPM/PBM concentrations at remote and urban sites of China ranged from 18.9 to $154 \mathrm{pg} \mathrm{m}^{-3}$ (mean $=51.8 \mathrm{pg} \mathrm{m}^{-3}$, $n=8$ ) and from 141 to $1180 \mathrm{pg} \mathrm{m}^{-3}$ (mean $=530 \mathrm{pg} \mathrm{m}^{-3}$, $n=9$ ), respectively, significantly higher (several to dozens of times) than the observations in North America and Europe (Table 1). The elevated TPM/PBM concentrations in urban areas were most likely due to local anthropogenic emissions (Z. W. Wang et al., 2006; Xiu et al., 2005; Fu et al., 2011a). PBM has an atmospheric residence time ranging from a few hours to a few weeks and can undergo regional transport and further influence PBM at the remote sites (Sheu and Mason, 2001). A positive correlation exists between PBM and GEM concentrations observed at remote and urban sites in China 
Table 1. Atmospheric Hg concentrations at ground-based stations in China and other regions worldwide.

\begin{tabular}{|c|c|c|c|c|c|c|c|c|c|}
\hline \multirow[b]{2}{*}{ Site } & \multicolumn{3}{|c|}{ Location } & \multirow[b]{2}{*}{ Type } & \multirow[b]{2}{*}{ Study period } & \multirow[b]{2}{*}{$\begin{array}{r}\text { GEM } \\
\left(\mathrm{ng} \mathrm{m}^{-3}\right)\end{array}$} & \multirow[b]{2}{*}{$\begin{array}{r}\mathrm{PBM} / \mathrm{TPM} \\
\left(\mathrm{pg} \mathrm{m}^{-3}\right)\end{array}$} & \multirow[b]{2}{*}{$\begin{array}{r}\mathrm{GOM} \\
\left(\mathrm{pg} \mathrm{m}^{-3}\right)\end{array}$} & \multirow[b]{2}{*}{ Reference } \\
\hline & Lon & Lat & $\begin{array}{l}\text { Altitude } \\
\text { (m a.s. } 1)\end{array}$ & & & & & & \\
\hline \multirow[t]{2}{*}{ Mt. Changbai } & $128.112^{\circ} \mathrm{E}$ & $42.402^{\circ} \mathrm{N}$ & 740 & Remote forest & $10 / 2008-10 / 2010$ & $1.60 \pm 0.51$ & & & Fu et al. (2012b) \\
\hline & & & & & 07/2013-07/2014 & $1.73 \pm 0.48$ & $18.9 \pm 15.6$ & $5.7 \pm 6.8$ & (Fu et al., 2014) \\
\hline Mt. Waliguan & $100.898^{\circ} \mathrm{E}$ & $36.287^{\circ} \mathrm{N}$ & 3816 & Remote grassland & 09/2007-09/2008 & $1.98 \pm 0.98$ & $19.4 \pm 18.0$ & $7.4 \pm 4.8$ & Fu et al. (2012a) \\
\hline Mt. Ailao & $101.017^{\circ} \mathrm{E}$ & $24.533^{\circ} \mathrm{N}$ & 2450 & Remote forest & $05 / 2011-05 / 2012$ & $2.09 \pm 0.63$ & $31.3 \pm 28.0$ & $2.2 \pm 2.3$ & Zhang et al. (2015b) \\
\hline Chengshantou & $122.68^{\circ} \mathrm{E}$ & $37.38^{\circ} \mathrm{N}$ & 30 & Remote coast & $07 \& 10 / 2007,01 \& 04 / 2009$ & $2.31 \pm 0.74$ & & & Ci et al. (2011a) \\
\hline Chongming Island & $121.908^{\circ} \mathrm{E}$ & $31.522^{\circ} \mathrm{N}$ & 11 & Remote coast & $09-12 / 2009$ & $2.50 \pm 1.50$ & & & Dou et al. (2013) \\
\hline Shangri-La & $99.733^{\circ} \mathrm{E}$ & $28.017^{\circ} \mathrm{N}$ & 3580 & Remote forest & $11 / 2009-10 / 2010$ & $2.55 \pm 2.73$ & $37.8 \pm 31.0$ & $7.9 \pm 7.9$ & Zhang et al. (2015a) \\
\hline Mt. Leigong & $108.2^{\circ} \mathrm{E}$ & $26.39^{\circ} \mathrm{N}$ & 2178 & Remote forest & 05/2008-05/2009 & $2.80 \pm 1.51$ & & & Fu et al. (2010b) \\
\hline Wanqingsha & $113.55^{\circ} \mathrm{E}$ & $22.7^{\circ} \mathrm{N}$ & 3 & Remote coast & $11-12 / 2009$ & 2.94 & & & Li et al. (2011) \\
\hline Miyun & $116.775^{\circ} \mathrm{E}$ & $40.481^{\circ} \mathrm{N}$ & 220 & Remote forest & $12 / 2008-11 / 2009$ & $3.22 \pm 1.94$ & $98.2 \pm 113$ & $10.1 \pm 18.8$ & Zhang et al. (2013) \\
\hline Mt. Damei & $121.565^{\circ} \mathrm{E}$ & $29.632^{\circ} \mathrm{N}$ & 550 & Remote forest & $04 / 2011-04 / 2013$ & $3.31 \pm 1.44$ & $154 \pm 104$ & $6.3 \pm 3.9$ & Yu et al. (2015) \\
\hline Mt. Gongga & $102.117^{\circ} \mathrm{E}$ & $29.649^{\circ} \mathrm{N}$ & 1640 & Remote forest & 05/2005-07/2007 & $3.98 \pm 1.62$ & $30.7 \pm 32.0^{*}$ & $6.2 \pm 3.9$ & Fu et al. (2008a); Fu et al. (2008b) \\
\hline Mt. Dinghu & $112.549^{\circ} \mathrm{E}$ & $23.164^{\circ} \mathrm{N}$ & 700 & Remote forest & 09/2009-04/2010 & $5.07 \pm 2.89$ & & & Chen et al. (2013) \\
\hline Mt. Jiuxian & $118.11^{\circ} \mathrm{E}$ & $25.71^{\circ} \mathrm{N}$ & 1700 & Remote forest & $11 / 2010,01 \& 04 \& 08 / 2011$ & & $24.0 \pm 14.6$ & & Xu et al. (2013) \\
\hline \multirow[t]{2}{*}{ Shanghai } & $121.54^{\circ} \mathrm{E}$ & $31.23^{\circ} \mathrm{N}$ & 19 & Urban & $08-09 / 2009$ & $2.70 \pm 1.70$ & & & Friedli et al. (2011) \\
\hline & & & & & 07/2004-04/2006 & & $560 \pm 220^{*}$ & & Xiu et al. (2009) \\
\hline Qingdao & $120.5^{\circ} \mathrm{E}$ & $36.16^{\circ} \mathrm{N}$ & 40 & Urban & $01 / 2013$ & $2.80 \pm 0.90$ & $245 \pm 174^{*}$ & & Zhang et al. (2014) \\
\hline Xiamen & $118.05^{\circ} \mathrm{E}$ & $24.60^{\circ} \mathrm{N}$ & 7 & Urban & $03 / 2012-02 / 2013$ & $3.50 \pm 1.61$ & $174 \pm 280$ & $61 \pm 69$ & Xu et al. (2015) \\
\hline Ningbo & $121.544^{\circ} \mathrm{E}$ & $29.867^{\circ} \mathrm{N}$ & 10 & Urban & $10 / 2007-01 / 2008$ & $3.79 \pm 1.29$ & & & Nguyen et al. (2011) \\
\hline Guangzhou & $113.355^{\circ} \mathrm{E}$ & $23.124^{\circ} \mathrm{N}$ & 60 & Urban & $11 / 2010-10 / 2011$ & $4.60 \pm 1.60$ & & & Chen et al. (2013) \\
\hline Jiaxing & $120.7^{\circ} \mathrm{E}$ & $30.833^{\circ} \mathrm{N}$ & 10 & Urban & $09 / 2005$ & $5.40 \pm 4.10$ & & & Wang et al. (2007) \\
\hline Chongqing & $106.5^{\circ} \mathrm{E}$ & $29.6^{\circ} \mathrm{N}$ & 350 & Urban & 08/2006-09/2007 & $6.74 \pm 0.37$ & & & Yang et al. (2009) \\
\hline \multirow{2}{*}{ Nanjing } & $118.78^{\circ} \mathrm{E}$ & $32.05^{\circ} \mathrm{N}$ & 100 & Urban & $01-12 / 2011$ & $7.90 \pm 7.00$ & & & Zhu et al. (2012) \\
\hline & & & & & 06/2011-02/2012 & & $1100 \pm 570^{*}$ & & Zhu et al. (2014) \\
\hline \multirow[t]{3}{*}{ Guiyang } & $106.72^{\circ} \mathrm{E}$ & $26.57^{\circ} \mathrm{N}$ & 1040 & Urban & $11 / 2011-11 / 2002$ & $8.40 \pm 4.87$ & & & Feng et al. (2004) \\
\hline & & & & & $12 / 2009-11 / 2010$ & $10.2 \pm 7.06$ & & & Fu and Feng (2015) \\
\hline & & & & & $08-12 / 2009$ & $9.72 \pm 10.2$ & $368 \pm 276$ & $35.7 \pm 43.9$ & Fu et al. (2011a) \\
\hline \multirow[t]{3}{*}{ Beijing } & $116.392^{\circ} \mathrm{E}$ & $38.898^{\circ} \mathrm{N}$ & 48 & Urban & $02 \& 09 / 1998$ & $10.4 \pm 3.25$ & & & Liu et al. (2002) \\
\hline & & & & & $01-12 / 2006$ & & 272 & & Schleicher et al. (2015) \\
\hline & & & & & & & $573 \pm 551^{*}$ & & \\
\hline Wuhan & $114.3^{\circ} \mathrm{E}$ & $30.6^{\circ} \mathrm{N}$ & 20 & Urban & -12002 & 14.8 & & & Xiang and Liu (2008) \\
\hline Changchun & $125.319^{\circ} \mathrm{E}$ & $43.824^{\circ} \mathrm{N}$ & 270 & Urban & $-/ 2001$ & 18.4 & $276^{*}$ & & Fang et al. (2004) \\
\hline \multirow[t]{2}{*}{ Lanzhou } & $103.79^{\circ} \mathrm{E}$ & $36.067^{\circ} \mathrm{N}$ & 1540 & Urban & $-/ 2004$ & 28.6 & & & Su et al. (2007) \\
\hline & & & & & $04 \& 07 \& 10 \& 12 / 1994$ & & $955^{*}$ & & Duan and Yang (1995) \\
\hline Southeastern coastal cities & & & & Urban & $11 / 2010,01 \& 04 \& 08 / 2011$ & & $141 \pm 128$ & & Xu et al. (2013) \\
\hline Suriname, South America & $56.983 \mathrm{~W}$ & $5.933^{\circ} \mathrm{N}$ & & Remote & 03-07/2007 & 1.40 & & & Müller et al. (2012) \\
\hline Cape Point, South Africa & $18.483^{\circ} \mathrm{E}$ & $34.35^{\circ} \mathrm{S}$ & 230 & Remote & $01-12 / 2009$ & 0.87 & & & Slemr et al. (2011) \\
\hline \multirow[t]{7}{*}{ Cape Grim, Australia } & $144.683^{\circ} \mathrm{E}$ & $40.683^{\circ} \mathrm{S}$ & & Remote & $2011-02013$ & $0.85-0.96$ & & & Slemr et al. (2015) \\
\hline & orth America & & & Urban & & $1.60-4.50$ & $2.5-25.4$ & $6.9-37.2$ & $\begin{array}{l}\text { Peterson et al. (2009); Song et al. (2009); Engle et al. (2010); } \\
\text { Liu et al. (2010); Brooks et al. (2010); Lan et al. (2012) }\end{array}$ \\
\hline & & & & Remote & & $1.32-1.66$ & $1.6-13.7$ & $0.5-5.6$ & Lan et al. (2012); Cole et al. (2013) \\
\hline & Europe & & & Urban & & $1.9-3.4$ & 12.5 & 2.5 & Dommergue et al. (2002); Li et al. (2008) \\
\hline & & & & Remote & & $1.40-1.93$ & $3.0-32.2$ & $9.1-26.5$ & Slemr and Scheel (1998); Lee et al. (1998); \\
\hline & & & & & & & & & Munthe et al. (2003); Kock et al. (2005) \\
\hline & Antarctic & & & Remote & & $0.23-1.20$ & $116-344$ & $12-224$ & Dommergue et al. (2010) \\
\hline
\end{tabular}

(PBM/TPM: * Indicates TPM (total particulate-bound mercury) and the rest indicate PBM (particulate-bound mercury on particles with an aerodynamic diameter < 2.5 $\mu$ m.)

(Fig. 3), indicating PBM and GEM shared common emission sources. Size-fractionation of particulate $\mathrm{Hg}$ in Beijing, Nanjing, and several coastal cities of southeastern China has been investigated. The studies revealed that PBM (the fraction associated with particles having a diameter of $<2.5 \mu \mathrm{m}$ ) constituted $40-70 \%$ of TPM. Given that fine particles are removed from the atmosphere less efficiently than large particles (Zhang et al., 2001), it is possible that the fraction of PBM in TPM in remote areas is higher than that in urban areas.

The fraction $(1.0-17.2 \%)$ of TPM/PBM in total atmospheric $\mathrm{Hg}$ ( $\mathrm{THg}$, defined as the sum of TGM and $\mathrm{TPM} / \mathrm{PBM})$ in the urban and remote areas of China was larger than that $(0.1-1.2 \%)$ in North America and Europe (Table 1). The fraction of TPM in THg at the urban sites of northern and eastern China was particularly high (5.2$17.2 \%$ as compared to the overall mean fraction at $2.5 \%$ ), and higher than the emission ratios of TPM/THg from most anthropogenic emission sources (L. Zhang et al., 2015). These results imply that secondary formation of TPM via gas-particle partitioning TGM is an important source of atmospheric TPM in urban areas of China. Atmospheric particulate matter (PM) pollution is a special concern in China. The concentrations of $\mathrm{PM}_{2.5}$ in eastern and northern China are the highest in the world (van Donkelaar et al., 2010). Elevated atmospheric PM probably facilitates the formation of TPM in the atmosphere, which can explain the large fraction of TPM. The two highest $\mathrm{PBM} / \mathrm{THg}$ ratios at remote sites were observed at Mt. Damei (4.4\%) and Miyun (3.0\%); both are located in the major anthropogenic source regions in eastern China (Fig. 1). The PBM/THg ratios (1.0-1.5\%) at the other four remote sites in northeastern, northwestern, and southwestern China are relatively lower. This is consistent with the spatial distribution of anthropogenic $\mathrm{Hg}$ emissions and atmospheric PM pollution in China (van Donkelaar et al., 2010; AMAP/UNEP, 2013). PBM is more readily removed from the atmosphere than GEM. Therefore, the PBM/THg ratios are expected to be higher near emission sources. 


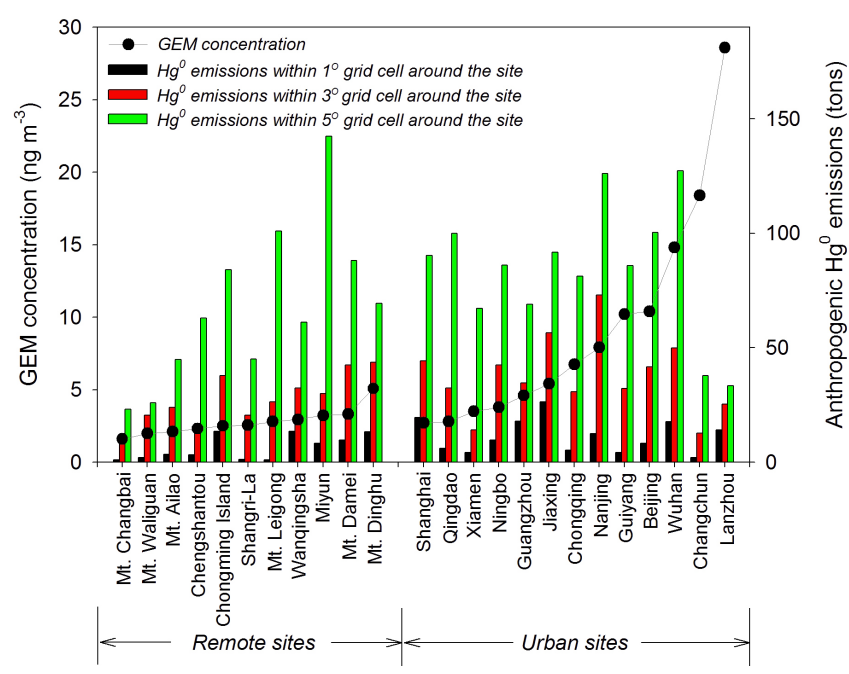

Figure 2. Atmospheric GEM concentrations and total anthropogenic $\mathrm{Hg}^{0}$ emissions within the $1^{\circ} \times 1^{\circ}, 3^{\circ} \times 3^{\circ}$, and $5^{\circ} \times 5^{\circ}$ grid cells surrounding the ground-based sites in mainland China.

\subsubsection{GOM concentrations}

GOM concentrations in urban areas have been measured in Guiyang (southwestern China) and Xiamen (southeastern China). Mean concentrations of GOM in Guiyang and Xiamen were 35.7 and $61.0 \mathrm{pg} \mathrm{m}^{-3}$, respectively (Table 1), higher than most observations in the urban areas of North America and Europe (typically $<15 \mathrm{pg} \mathrm{m}^{-3}$ ), except in St. Louis, Missouri, USA (GOM mean $=37.2 \mathrm{pg} \mathrm{m}^{-3}$ ), and Reno, Nevada, USA (GOM mean $=26.0 \mathrm{pg} \mathrm{m}^{-3}$; Peterson et al., 2009; Engle et al., 2010). The former was heavily impacted by nearby sources and the latter was influenced by in situ production and mixing of GOM from the free troposphere (Peterson et al., 2009; Engle et al., 2010). In China, anthropogenic emission is the dominant factor contributing to the elevated GOM concentrations in urban areas. Transient high GOM concentrations were often associated with plumes from a coal-fired power plant and a cement factory in Guiyang (Fu et al., 2011a).

Mean GOM concentrations at seven remote sites of China ranged from 2.2 to $10.1 \mathrm{pg} \mathrm{m}^{-3}$ (mean $=6.6 \pm 2.4 \mathrm{pg} \mathrm{m}^{-3}$ ), significantly lower than those observed in urban areas ( $t$ test, $p<0.01)$ and comparable to the values in Europe and North America ( $t$ test, $p=0.21$; Table 1$)$. Sources of GOM at remote sites include local emissions, in situ photochemical production, and intrusion of GOM-enriched air from the free troposphere. At the remote sites in eastern and northern China, the local sources (such as domestic heating in small settlements) may be responsible for the elevated GOM concentrations. The impact of long-range transport from industrial and urbanized areas is rare. GOM has a much greater dry deposition velocity $\left(0.1-7.6 \mathrm{~cm} \mathrm{~s}^{-1}\right)$ than GEM $\left(0.01-0.3 \mathrm{~cm} \mathrm{~s}^{-1}\right)$ and PBM (0.02-2.1 $\mathrm{cm} \mathrm{s}^{-1}$; Zhang et al., 2009), and there-

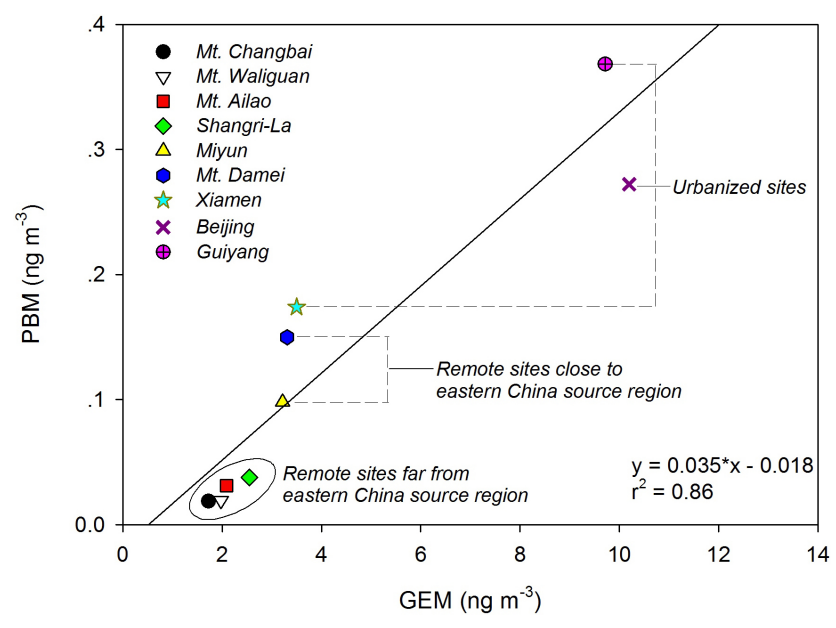

Figure 3. Correlation between GEM and PBM $\left(\mathrm{Hg}-\mathrm{P}_{2.5}\right)$ concentrations in remote and urban areas of China.

fore it has a much shorter atmospheric residence time and limited long-range transport (Lindberg and Stratton, 1998). However, under low air humidity and high wind speed, the possibility of regional transport of GOM cannot be ruled out. For example, the observation at Mt. Waliguan, northeastern Tibetan Plateau, found many high-GOM events were related to air plumes originating from industrial and urbanized centers that are about $90 \mathrm{~km}$ to the east of the sampling site (Fu et al., 2012a). Several studies observed a remarkable diel pattern of GOM with higher concentrations during daytime that cannot be explained by emissions (Fu et al., 2012a; Zhang et al., 2013). Although not as significant as in the polar region, free troposphere and marine boundary layer (Lindberg et al., 2002; Swartzendruber et al., 2006; Timonen et al., 2013), in situ GOM production may be an important source of GOM in remote areas of China. There is currently no evidence suggesting the mixing of GOM-enriched air from the upper troposphere/lower stratosphere in China because most of the sampling sites are located in low-altitude areas or the site characteristics do not favor intrusion of an air mass from the upper atmosphere.

\subsection{Atmospheric $\mathrm{Hg}$ in the marine boundary layer}

The first measurement of GEM in the marine boundary layer near China was made onboard a ship during a cruise campaign in the South China Sea (SCS) in August 2007 (Fu et al., 2010c). The SCS is surrounded by China, Vietnam and Laos in the Indo-China Peninsula, and the Philippines. The GEM concentration displayed a spatial pattern with concentrations (1.29-1.94 $\mathrm{ng} \mathrm{m}^{-3}$ ) in the open sea close to the background values $\left(1.5-1.7 \mathrm{ng} \mathrm{m}^{-3}\right)$ in the Northern Hemisphere and with elevated concentrations $\left(2.5-4.71 \mathrm{ng} \mathrm{m}^{-3}\right)$ at locations close to mainland China (Fig. 4). Most elevated GEM events were associated with air masses from southern China and the Indo-China Peninsula (Fu et al., 2010c). Atmospheric 


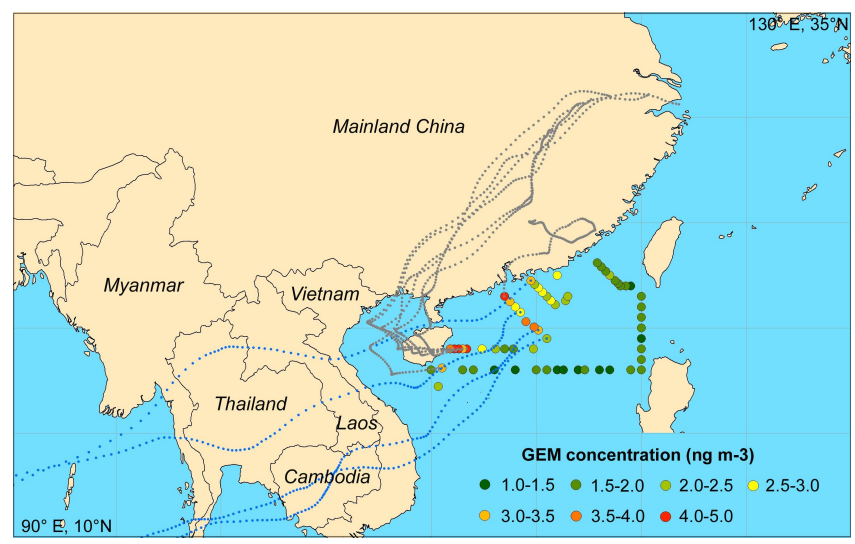

Figure 4. Spatial distribution of GEM concentrations and backwards trajectories in the marine boundary layer of the South China Sea (Fu et al., 2010c).

$\mathrm{Hg}$ emissions from mainland China have been investigated extensively (Streets et al., 2005; Wu et al., 2006; Shetty et al., 2008). However, Hg emissions in the Indo-China Peninsula are not well understood. The mean GEM concentration in Da Nang, central eastern Vietnam, was reported to be up to $3.86 \mathrm{ng} \mathrm{m}^{-3}$, suggesting significant anthropogenic $\mathrm{Hg}$ emissions in the Indo-China Peninsula (Sheu et al., 2013). Outflows of $\mathrm{Hg}$ from mainland China and the Indo-China Peninsula to the SCS vary with the monsoonal climate (Fu et al., 2010c). The cruise measurements by Fu et al. (2010c) were conducted in summer and the observations do not suggest impact of $\mathrm{Hg}$ outflows from China and the Indo-China Peninsula on the open sea of the SCS because of the southeastern monsoonal winds. However, as the northwestern monsoonal winds become predominant in winter and spring, the impact of $\mathrm{Hg}$ emissions in China and the Indo-China Peninsula into the SCS is expected to increase. For example, the mean GEM concentration in Dongsha Island of the SCS in spring (March-April, 2008) was 56\% higher than that in summer (August, 2008; Sheu et al., 2013).

GEM in the marine boundary layer was also investigated in the Bohai Sea and Yellow Sea from 9 to 18 July 2010 (Ci et al., 2011b). A mean GEM concentration of $2.61 \pm 0.50 \mathrm{ng} \mathrm{m}^{-3}$ was reported, similar to the values observed in the SCS (Fu et al., 2010c) and significantly higher than those measured in the Atlantic Ocean, North Sea, Baltic Sea, Adriatic Sea, and Mediterranean Sea (Leermakers et al., 1997; Wangberg et al., 2001; Temme et al., 2003; Gardfeldt et al., 2003; Sprovieri and Pirrone, 2008). A GEM concentration gradient from the Chinese coast to the eastern Bohai Sea and Yellow Sea was observed (Ci et al., 2011b). Elevated GEM concentrations were mostly related to the outflows from China ( $\mathrm{Ci}$ et al., 2011b). GEM concentrations were slightly higher in the Yellow Sea $\left(1.50-2.50 \mathrm{ng} \mathrm{m}^{-3}\right)$ compared to the nearby western Korea coast (1.40-2.00 $\mathrm{ng} \mathrm{m}^{-3}$; Nguyen et al., 2011). GEM concentrations in the marine boundary layer of the East China Sea (ECS) were measured onboard during the cruise campaign from Shanghai, China, to the Antarctic (Xia et al., 2010). A mean concentration of $2.32 \pm 0.49 \mathrm{ng} \mathrm{m}^{-3}$ in the ECS and the coast of Japan and Korea was observed (Xia et al., 2010). These studies show that anthropogenic $\mathrm{Hg}$ emissions in China have a strong impact on the observed GEM concentration in marine areas east of China.

\subsection{Atmospheric $\mathrm{Hg}$ in the free troposphere and lower stratosphere}

GEM concentrations in the upper troposphere/lower stratosphere (10-12 km above sea level) over mainland China were measured onboard a passenger aircraft during dozens of CARIBIC flights from Frankfurt, Germany, to Guangzhou, China (Slemr et al., 2009, 2014; Lai et al., 2011). The GEM concentrations were in the range of $0.5-1.5 \mathrm{ng} \mathrm{m}^{-3}$ for most cases, except near Guangzhou, China, where a GEM concentration exceeding $2.0 \mathrm{ng} \mathrm{m}^{-3}$ was observed. Aircraft measurements of GEM over the South China Sea (SCS) in flights from Guangzhou, China, to Manila, Philippines (Lai et al., 2011), showed a concentration range of $0.8-1.8 \mathrm{ng} \mathrm{m}^{-3}$. These GEM levels are comparable to the high-altitude observations made over southern Europe, western Africa, Atlantic Ocean, and western South America (Slemr et al., 2009, 2014) as well as North America and the North Pacific Ocean (Talbot et al., 2007; Lyman and Jaffe, 2012). Concentrations of ozone, halogen species and other oxidants in the upper troposphere/lower stratosphere are highly elevated and can facilitate depletion of GEM (Slemr et al., 2009; Lyman and Jaffe, 2012; Talbot et al., 2007). Also, the upper troposphere/lower stratosphere has high horizontal wind speed and weak vertical mixing. Hence, the GEM concentrations measured at high altitude over China were similar to the global level of GEM concentrations in the upper troposphere/lower stratosphere.

Nevertheless, several high-GEM events in the upper troposphere/lower stratosphere over mainland China were observed (Slemr et al., 2009). These events were accompanied by elevated $\mathrm{CO}$, aerosols, $\mathrm{NO}_{y}$, and $\mathrm{CH}_{3} \mathrm{CN}$ concentrations transported from the planetary boundary layer over southern China (Slemr et al., 2009). In a transport event in July 2007, the GEM concentrations in the upper troposphere/lower stratosphere were elevated to $2.0-4.0 \mathrm{ng} \mathrm{m}^{-3}$. This event was impacted by anthropogenic sources in southern China via strong convective processes (Lai et al., 2011). The emission plumes from mainland China on GEM were also detected in the free troposphere during the flights over East Asia (Friedli et al., 2004), which reported several strong GEM pollution events with concentrations exceeding $2.5 \mathrm{ng} \mathrm{m}^{-3}$ (up to $6.3 \mathrm{ng} \mathrm{m}^{-3}$; Friedli et al., 2004). 


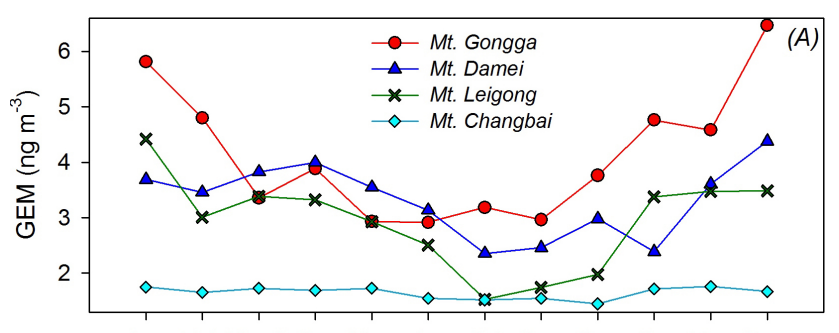

Jan Feb March Apr May Jun Jul Aug Sep Oct Nov Dec

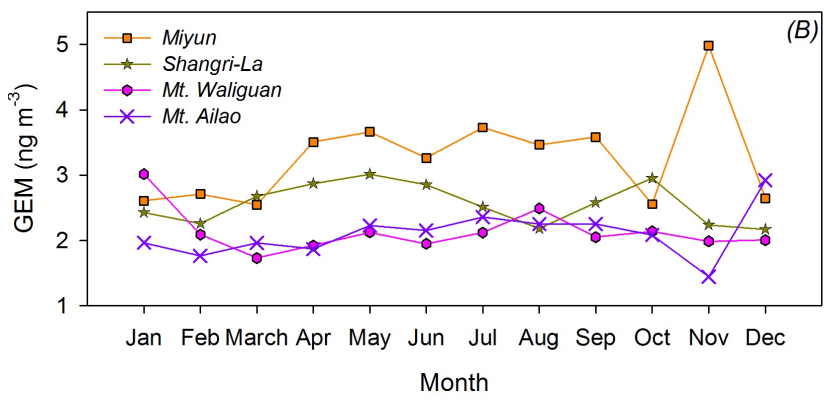

Figure 5. Monthly variations of GEM concentrations at remote sites of China.

\subsection{Seasonal variations of GEM and the influence of monsoon}

Figure 5 shows the seasonal variations of GEM concentration at ground-based remote sites in China. The variations can be classified into two distinct types (Fig. 5a and b). The mean GEM concentrations at Mt. Gongga, Mt. Daimei, Mt. Leigong, and Mt. Changbai in cold seasons (from October to March) were significantly higher ( $t$ test: $p<0.05$ for all) than that in warm seasons (from April to September). On the other hand, the means of GEM at Miyun, Shangri-la, Mt. Ailao, and Mt. Waliguanin warm seasons were relatively higher (2$17 \%)$ than that in cold seasons, although the differences were not significant ( $t$ test: $p=0.06-0.66$ ). Seasonal variations of GEM concentrations in urban areas of China were also different among sites. In Guiyang (southwestern China) and Xiamen (southeastern China), monthly mean GEM concentrations were significantly higher ( $t$ test: $p<0.05$ for both) in cold seasons than that in warm seasons (Feng et al., 2004; $\mathrm{Xu}$ et al., 2015). In contrast, monthly mean GEM concentrations in Nanjing (eastern China) were found to be $\sim 60 \%$ higher in warm seasons than cold seasons ( $t$ test: $p<0.05$; Zhu et al., 2012). In Guangzhou (southern China), the lowest concentration occurred in summer and the maximum was observed in spring ( $22 \%$ higher; Chen et al., 2013).

Several hypotheses have been made to explain the seasonal variations of GEM in China, including seasonal changes in anthropogenic GEM emissions and natural emissions. The seasonal emission changes mainly resulted from coal combustion for urban and residential heating during cold seasons. This source lacks emission control devices and releases large amounts of $\mathrm{Hg}$ capped by a shallow planetary bound- ary layer, leading to elevated GEM concentrations at some of the monitoring sites in cold seasons (Feng et al., 2004; Fu et al., 2008a, 2010b). GEM emission from natural surfaces is influenced by many factors (Gustin et al., 2008; Zhang et al., 2009). Due to increasing solar radiation and soil/air temperature, elevated GEM emission fluxes from soil and water in warm seasons were frequently observed (Fu et al., 2012c), which may partially explain the higher GEM concentrations in Nanjing in warm seasons. However, emissions from domestic heating during winter could not explain the lower winter GEM concentrations observed at Miyun, Shangri-La, Mt. Waliguan and Mt. Ailao (Fig. 5b), and the higher natural emissions in summer could not explain the lower summer GEM concentrations measured at Mt. Gongga, Mt. Damei, Mt. Leigong, and Mt. Changbai (Fig. 5a). This implies other not-yet-understood factors that played a role in the observed GEM seasonal variation.

The northerly winter monsoon (northwestern monsoon) and East Asian summer monsoon (southwestern and southeastern monsoon) strongly influence the seasonal winds in East Asia (An, 2000). Summer winds in eastern China mainly originate from the Indian Ocean and the western Pacific Ocean and then move northwards from southern China to northern China, while winter winds mainly originate from Siberia and western Asia and then move southwards from northern China to southern and eastern China (Fig. 6). Given the spatial patterns of anthropogenic GEM emissions in China and East Asia (Fig. 1), monsoonal winds can change the source-receptor relationships at observational sites and subsequently the seasonal GEM trends. Here we calculated the anthropogenic GEM sources impacted factors (ASIF, a conditional possibility of GEM transport from regional source regions to a receptor) for the ground-based sites in China (Fig. 7). The sites located in western, southwestern, and northern China yielded higher ASIF values in the warm season because GEM source regions were upwind under the influence of the East Asian summer monsoon. Nanjing (eastern China) also showed a larger ASIF in the warm season because easterly winds passed through the Yangtze River delta (one of the most important GEM source regions in China, Fig. 1) prior to arriving in Nanjing. The sites in southern, eastern, and northeastern China showed higher ASIF values in the cold season due to transport of anthropogenic emissions of GEM from the north and west by the northerly winter monsoon. As shown in Fig. 7, the variations of ASIF values in the cold and warm seasons at remote and urban sites of China were in a good agreement with the variations of atmospheric GEM concentrations (except at Mt. Gongga). Monsoonal winds do not have a noticeable influence in the Mt. Gongga area due to the mountainous barrier (the elevation of the summit of Mt. Gongga is $7556 \mathrm{~m}$ a.s.1.). Under such circumstances, other factors, including local and regional GEM emissions, atmospheric photochemical processes, mixing layer depth, and meteorologi- 
cal conditions played a more important role in the observed seasonal variation.

Seasonal variations of TPM/PBM mostly showed lower concentrations in summer and higher concentrations (up to 1 order of magnitude higher) in winter and fall (Z.W. Wang et al., 2006; Fu et al., 2008b; Zhu et al., 2014; Xu et al., 2015; Xiu et al., 2009; Zhang et al., 2013). The higher TPM/PBM in winter was likely caused by direct PBM emissions, formation of secondary particulate mercury via gas-particle partitioning and a lack of wet scavenging processes ( $\mathrm{Z}$. W. Wang et al., 2006; Fu et al., 2008b; Zhu et al., 2014). Data regarding the seasonal variation of GOM concentrations were sparse. The observations at Mt. Gongga (southwestern China) and Miyun (northern China) showed lower GOM concentrations in winter, opposite to the seasonal patterns of GEM (Fu et al., 2008b; Zhang et al., 2013). Possible explanations include stronger gas-particle partitioning of GOM at lower air temperature and higher PM concentrations in winter, as well as faster photochemical production of GOM in warm seasons (Fu et al., 2008b; Zhang et al., 2013).

\subsection{Diel variations of atmospheric $\mathrm{Hg}$}

Figure 8 displays the diel variations of GEM at the remote sites in China. Most observations showed elevated concentrations during daytime except at Mt. Waliguan and Miyun. Such a diel pattern highlights the impact of regional anthropogenic $\mathrm{Hg}$ emissions. Most of these remote sampling sites are located at high altitude far away from major source areas, and therefore were influenced by the diel transition of mountain valley breezes that brought $\mathrm{Hg}$-polluted air to the sampling sites during daytime (Fu et al., 2008a, 2010b; Chen et al., 2013). The higher concentrations during nighttime at Mt. Waliguan were mainly related to downward intrusion of free troposphere airflow originating from industrialized and urbanized areas via long-range transport (Fu et al., 2012a). For urban sites, diel trends of GEM in Guiyang, Hefei, Xiamen, and Guangzhou were similar, with higher concentrations at night due to the accumulation of $\mathrm{Hg}$ emitted from local sources in the shallow nocturnal boundary layer (Feng et al., 2004; Chen et al., 2013; Li, 2012). The diel trend of GEM in Nanjing exhibited higher concentrations from early morning to noon, which was attributable to natural emissions and downward mixing of air masses from aloft (Zhu et al., 2012).

Elevated PBM concentrations were observed at night in Guiyang, Mt. Waliguan, and Miyun. The most pronounced diel variation of PBM was observed in Guiyang, with the peak nighttime hourly PBM concentration observed about 9 times higher than the minimum observed during daytime, suggesting the accumulation of local PBM emissions at night (Fu et al., 2011a). The nighttime elevated PBM at Miyun was related to the formation of a temperature inversion layer (Zhang et al., 2013), while that at Mt. Waliguan was caused by downward intrusion of PBM-enriched air originating from regional industrialized and urbanized areas (Fu et al., 2012a).

GOM observations in China showed increasing concentrations during daytime, coinciding with increasing solar radiation and atmospheric oxidant concentrations ( $\mathrm{Fu}$ et al., 2008b, 2011a; Zhang et al., 2013; Zhang et al., 2015a). The diel trend of GOM is more pronounced at remote sites where the impact of anthropogenic emissions was weaker and in warm seasons when levels of atmospheric oxidants and solar radiation were high ( Fu et al., 2008b; Zhang et al., 2013). This result is consistent with the observations in North America and Europe (Munthe et al., 2003; Lan et al., 2012). Both anthropogenic sources and photochemical oxidation can give atmospheric GOM. Photochemical oxidation produces approximately 8000-15000 t of atmospheric GOM annually (Selin et al., 2007; Driscoll et al., 2013), about 10 20 times greater than the quantity of anthropogenic emissions. Although this process mainly occurred in the free troposphere, stratosphere, polar regions, and marine boundary layer (Lindberg et al., 2002; Swartzendruber et al., 2006; Fain et al., 2009; Lyman and Jaffe, 2012; Timonen et al., 2013), the diel pattern of GOM at the remote sites in China suggests that photochemical oxidation may also play an important role in the formation of GOM in the continental boundary layer.

\subsection{Long-term trend of GEM}

Gradual decreases in GEM concentrations in South Africa, Europe, and North America have been well documented (Slemr and Scheel, 1998; Slemr et al., 2003, 2011; Ebinghaus et al., 2002; Cole et al., 2013). Slemr et al. (2011) showed that GEM concentrations decreased from $\sim 1.35$ in 1996 to $\sim 0.9 \mathrm{ng} \mathrm{m}^{-3}$ in 2008 at Cape Point, South Africa, and from $\sim 1.75$ in 1996 to $\sim 1.4 \mathrm{ng} \mathrm{m}^{-3}$ in 2009 at Mace Head, Europe (a decrease of $0.024-0.035 \mathrm{ng} \mathrm{m}^{-3} \mathrm{yr}^{-1}$ or 1.4 $\left.2.7 \% \mathrm{yr}^{-1}\right)$. The 10-year trends of GEM concentrations at five ground-based sites in the Arctic and Canada also showed a decreasing trend at a rate of $0.013-0.035 \mathrm{ng} \mathrm{m}^{-3} \mathrm{yr}^{-1}(0.9-$ $2.2 \% \mathrm{yr}^{-1}$; Cole et al., 2013). Such a decrease is consistent with the decrease in anthropogenic $\mathrm{Hg}$ emissions in Europe and North America (Pacyna et al., 2006; Streets et al., 2011; AMAP/UNEP, 2013). The available GEM data in China are not sufficient to conclude a long-term concentration trend. However, a preliminary assessment can be obtained using monitoring data that spanned up to 7-9 years. For example, $\mathrm{Fu}$ and Feng (2015) found that the annual mean GEM concentration in Guiyang, southwestern China, increased from $8.40 \mathrm{ng} \mathrm{m}^{-3}$ (geomean $=7.46 \mathrm{ng} \mathrm{m}^{-3}$ ) in 2002 to $10.2 \mathrm{ng} \mathrm{m}^{-3}$ (geomean $=8.88 \mathrm{ng} \mathrm{m}^{-3}$ ) in 2010. Assuming a linear increasing rate, a mean annual rate of $0.16 \mathrm{ng} \mathrm{m}^{-3} \mathrm{yr}^{-1}\left(2.5 \% \mathrm{yr}^{-1}\right)$ was found. The increase in GEM in Guiyang was mainly observed during cold seasons (paired samples test: $p<0.05$ during the cold season vs. $p=0.82$ during the warm season), when the impact of long- 

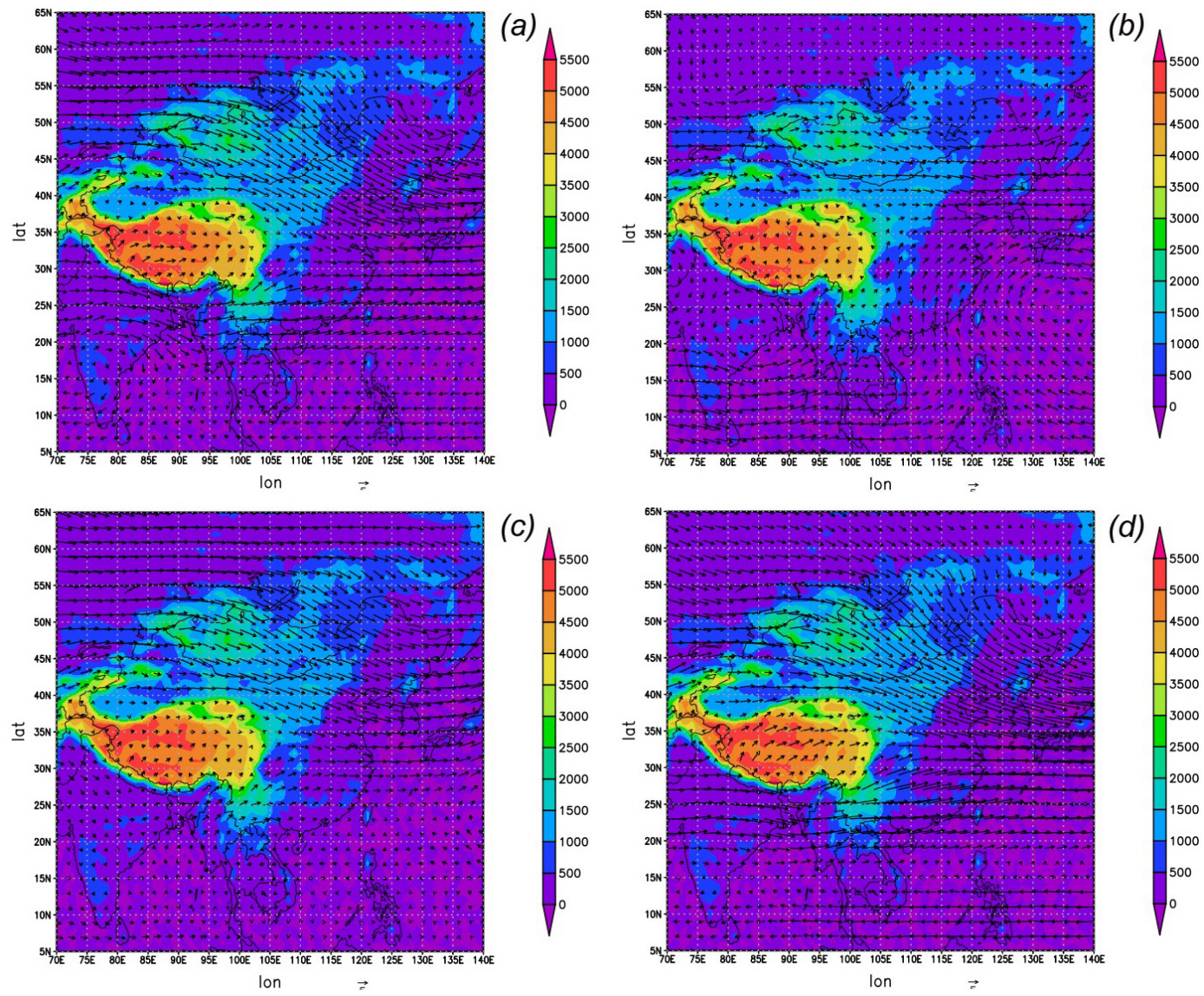

Figure 6. Wind field at $650 \mathrm{hPa}$ and geopotential height from 2011 to 2013: (a) spring, (b) summer, (c) fall and (d) winter. It was calculated using the Grid Analysis and Display System (GADS) and gridded meteorological data $\left(1.0^{\circ} \times 1.0^{\circ}\right)$ from the NCEP FNL Operational Global Analysis system.

range transport from major source regions of China played a more important role. The measurements at Mt. Changbai, northeastern China (unpublished data presented in the 12th ICMGP in Jeju, Korea, 2015) showed that the annual mean GEM concentrations were increasing during the 20092013 period with a mean of $1.75 \pm 0.09 \mathrm{ng} \mathrm{m}^{-3}$ in $2013 \mathrm{com}-$ pared to a mean of $1.55 \pm 0.31 \mathrm{ng} \mathrm{m}^{-3}$ in 2009 (paired samples test: $p<0.01$ ), corresponding to an annual increase of $0.04 \mathrm{ng} \mathrm{m}^{-3} \mathrm{yr}^{-1}\left(2.4 \% \mathrm{yr}^{-1}\right.$; Fig. 9). The increase in atmospheric GEM in Guiyang and Mt. Changbai is consistent with the increasing anthropogenic $\mathrm{Hg}$ emissions (4.2\% per year) in China (L. Zhang et al., 2015). After 2013, GEM concentrations at Mt. Changbai showed a slight decrease in 2014 and 2015. The long-term trend should be further evaluated using continuous monitoring data.

\subsection{Inferences on $\mathrm{Hg}$ emissions in China}

Field measurements of atmospheric $\mathrm{Hg}$ have been applied to constrain Hg emissions. Pan et al. (2007) used a GEM concentration measured onboard aircrafts and an inverse modeling method to estimate $\mathrm{Hg}$ emissions in China, which es- timated an annual GEM emission of $1140 \mathrm{t}$ in China, $~ 3.4$ times greater than the GEM emission estimated using activity statistics in China for 1999 (340 t). Using GEM observations at 27 remote sites globally (of which 4 sites are in mainland China) and GEOS-Chem inverse modeling, Song et al. (2015) predicted a total GEM emission of 1180-2030 $\mathrm{t}$ (median $=1550 \mathrm{t})$ from Asia, of which 650-1770 t (me$\operatorname{dian}=1210 \mathrm{t}$ ) were from anthropogenic sources. Estimates of GEM emission in China have also been made using correlation analysis using observed GEM and trace gas concentrations. This approach is based on the measured ratios of GEM to trace gases in plumes originating from China and verified inventories of trace gases in China. Table 2 summarizes the observed GEM / CO ratios in China. The GEM / CO correlation slopes varied slightly in different years without systematic changes. The variations of GEM / CO correlation slopes observed in different years and at the receptors may partially reflect spatial and seasonal patterns. Using published GEM / CO correlation slopes and CO emissions in China, the GEM emissions in China over the past decade were estimated to range from 632 to $1138 \mathrm{t}$ (Table 2), consistent with the re- 


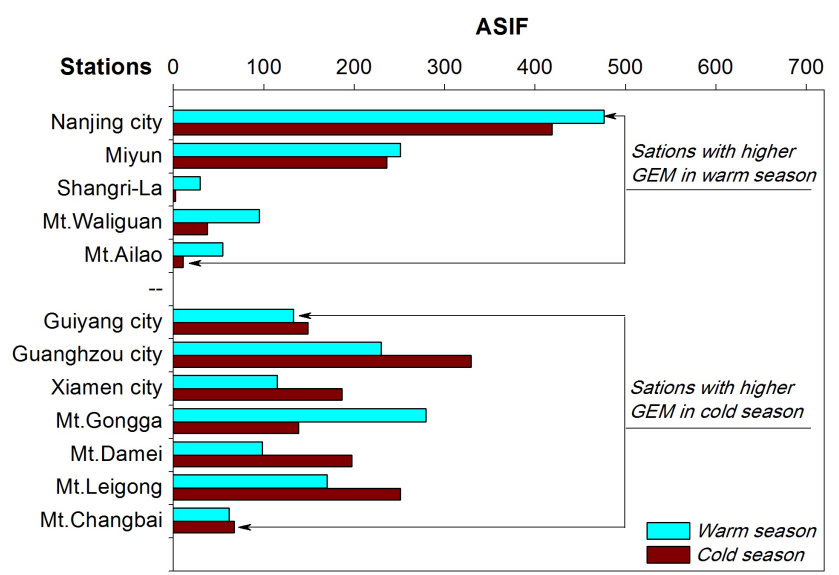

Figure 7. Dimensionless anthropogenic $\mathrm{Hg}^{0}$ sources impacted factor (ASIF) at Chinese ground-based stations in cold and warm seasons. ASIF is defined as ASIF $=\frac{\sum \mathrm{N}_{\mathrm{ij}} \times \mathrm{Hg}_{\mathrm{ij}}^{0}}{\sum \mathrm{N}_{\mathrm{ij}}}$, where $\mathrm{N}_{\mathrm{ij}}$ is the number of trajectory endpoints in a $0.5^{\circ} \times 0.5^{\circ}$ grid cell $(\mathrm{i}, \mathrm{j})$ during the sampling period, and $\mathrm{Hg}_{\mathrm{ij}}^{0}$ is the total anthropogenic $\mathrm{Hg}^{0}$ emissions in a $0.5^{\circ} \times 0.5^{\circ}$ grid cell $(\mathrm{i}, \mathrm{j})$. The source region domain contains $20 \times 20$ grid cells at a spatial resolution of $0.5^{\circ} \times 0.5^{\circ}$. The ground-based stations (receptors) are located in the center of the domain. The 5-day backward trajectory that ended at a height of $\sim 1000 \mathrm{~m}$ a.g.l. was utilized for the calculation of ASIF.

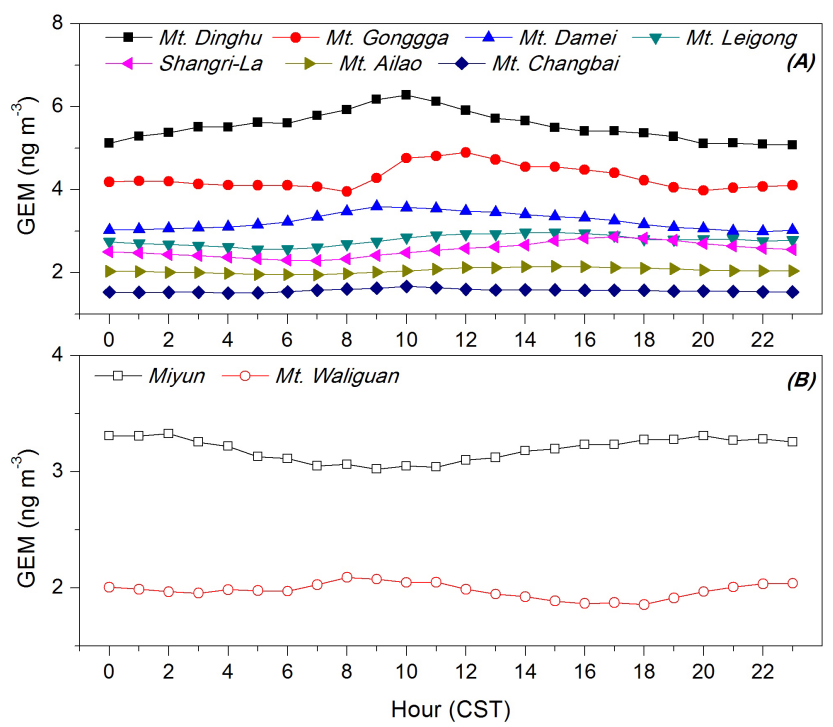

Figure 8. Diel trends of GEM concentrations at the remote sites in China. The diel trends at the remote sites in China were calculated on the basis of at least 1 year of continuous measurements (the time schedule for each of the sites was shown in Table 1).

sults derived from inverse modeling (Pan et al., 2006; Song et al., 2015). An overall increase in GEM emission from 2001 to 2009 was evident because of the increasing GEM / CO correlation slopes and $\mathrm{CO}$ emissions. $\mathrm{CO}$ emissions in China are not available from 2011 to 2012 and the estimated GEM

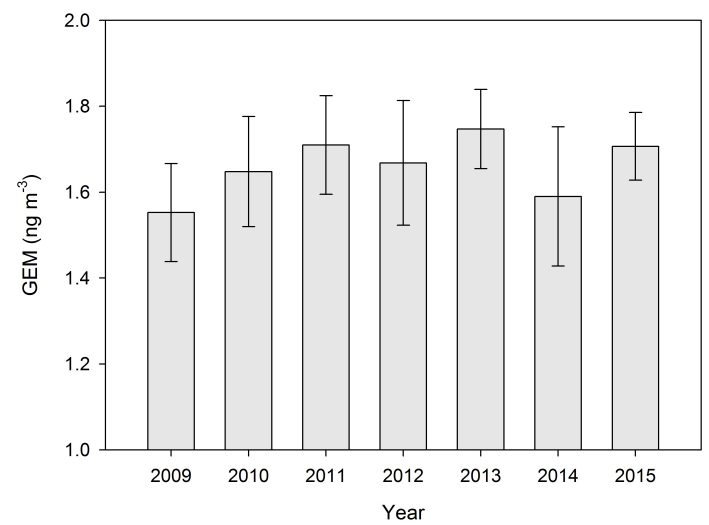

Figure 9. Annual mean GEM concentrations at Mt. Changbai in northeastern China.

emissions in the 2 years were based on $\mathrm{CO}$ emissions in 2010 (Tohjima et al., 2014), which could result in an underestimate of GEM. Considering the agreement between inverse modeling and correlation estimates, it is likely that GEM emissions in China are larger than the values estimated by activity statistics (312-430 $\mathrm{t} \mathrm{yr}^{-1}$; AMAP/UNEP, 2013; L. Zhang et al., 2015). Recent field measurements of $\mathrm{Hg}$ emission factors for large point sources have reduced the uncertainties in Hg emission estimates (Wang et al., 2014). However, knowledge gaps in the emission estimates in China remain for the source categories whose emission factors have not been verified. $\mathrm{Hg}$ emissions related to the production, consumption and recycling of $\mathrm{Hg}$ in artisanal mercury and gold production, polyvinyl chloride (PVC) production, mercury batteries, mercury sphygmomanometers, and mercury thermometers, are potentially large $\mathrm{Hg}$ sources in China but have not been well evaluated (Li et al., 2009; Ren et al., 2014; Minschwaner et al., 2010). Other reasons causing earlier underestimation include natural emissions and conversion of GOM and/or PBM to GEM in the stack or in the plume during transit (Jaffe et al., 2005).

\subsection{Long-range transport of atmospheric $\mathrm{Hg}$ as a result of $\mathrm{Hg}$ emissions and monsoon climate}

Anthropogenic $\mathrm{Hg}$ emissions in China are mainly from industrial and urban sources (D. Y. Wang et al., 2014). These sources not only cause highly elevated GEM concentrations locally, but also impact the GEM concentrations in remote areas via long-range transport. Fig. 10 shows the source regions of GEM at Mt. Waliguan (northwestern China), Mt. Changbai (northeastern China), Mt. Leigong (southwestern China) and Mt. Damei (eastern China) indicated by the potential source contribution function (PSCF). The source regions of Mt. Waliguan were industrialized and urbanized areas in northwestern China 100-400 km to the east of the sampling site and northern India (Fu et al., 2012a). The source regions of Mt. Changbai were the megacities of Beijing, Tianjin, and 
Table 2. GEM / CO ratios in air plumes and estimated GEM emissions in China.

\begin{tabular}{|c|c|c|c|c|c|c|}
\hline Source region & Year & Receptor & $\begin{array}{l}\text { GEM / CO ratio } \\
\left(\mathrm{pg} \mathrm{m}^{-3} / \mathrm{ppb}\right)\end{array}$ & $\begin{array}{r}\text { CO emission } \\
\left(\times 10^{6} \mathrm{tyr}^{-1}\right) ; \\
\text { Tohjima et al. }(2014)\end{array}$ & $\begin{array}{l}\text { Estimated GEM emission } \\
\left(\mathrm{t} \mathrm{yr}^{-1}\right)\end{array}$ & Reference \\
\hline $\begin{array}{l}\text { Eastern, northern, } \\
\text { and northeastern China }\end{array}$ & 2001 & ACE-Asia flight & $6.8 \pm 1.2(n=16)$ & 140 & 763 & $\begin{array}{l}\text { Friedli et al. (2004); } \\
\text { Pan et al. (2006) }\end{array}$ \\
\hline Eastern China & 2004 & $\begin{array}{l}\text { Hedo station, Japan } \\
\text { and MBO, USA }\end{array}$ & $4.4 \pm 1.4(n=10)$ & 179 & 632 & $\begin{array}{l}\text { Jaffe et al. (2005); } \\
\text { Weiss-Penzias et al. (2007) }\end{array}$ \\
\hline $\begin{array}{l}\text { Eastern and southern } \\
\text { China }\end{array}$ & 2005 & $\begin{array}{l}\text { MBO, USA and } \\
\text { CARIBIC flights }\end{array}$ & $7.1 \pm 1.5(n=3)$ & 182 & 1036 & $\begin{array}{l}\text { Weiss-Penzias et al. (2007); } \\
\text { Slemr et al. (2014) }\end{array}$ \\
\hline $\begin{array}{l}\text { Northwestern, southwestern, } \\
\text { and southern China }\end{array}$ & 2006 & CARIBIC flights & $7.6 \pm 6.8(n=16)$ & 176 & 1073 & Slemr et al. (2009) \\
\hline $\begin{array}{l}\text { Northwestern, southwestern, } \\
\text { and southern China }\end{array}$ & 2007 & CARIBIC flights & $8.4 \pm 3.2(n=9)$ & 169 & 1138 & $\begin{array}{l}\text { Slemr et al. (2009); } \\
\text { Sheu et al. (2010) }\end{array}$ \\
\hline Northwestern China & 2009 & Mt. Waliguan, China & $9.4 \pm 3.5(n=20)$ & 150 & 1130 & Fu et al. (2015) \\
\hline Southwestern and southern China & 2011 & Mt. Ailao, China & $6.4 \pm 6.1(n=8)$ & 159 & 812 & Fu et al. (2015) \\
\hline Southwestern and southern China & 2012 & Mt. Ailao, China & $6.2 \pm 2.0(n=7)$ & 159 & 791 & Fu et al. (2015) \\
\hline
\end{tabular}

Shijiazhuang (Fu et al., 2012b), similar to the source regions of Miyun, northern China (Zhang et al., 2013). The source regions of Mt. Leigong included Chongqing, Guiyang, and Kunming (three major cities in southwestern China) as well as northern Myanmar, where forest biomass burning released a large quantity of air pollutants to the atmosphere (Streets et al., 2003). The source regions of GEM at Mt. Damei were central Anhui Province and western Jiangshu Province, both being important industrial regions in eastern China (Yu et al., 2015). These source regions corresponded to the locations of $\mathrm{Hg}$ emission sources in China and other Asian countries (Fig. 1). These results elucidated that the dominant transport routes of GEM are highly related to dominant wind directions governed by the monsoons. On the other hand, local emission sources played a more predominant role in urban areas (Fu et al., 2011a; Zhu et al., 2012).

Air outflows from mainland China may also impact GEM concentrations in other regions. For instance, measurements of atmospheric GEM in Seoul, Korea, showed that approximately $79 \%$ of the high-GEM events were related to air masses originating from China (Choi et al., 2009). Flight measurements in the free troposphere over the Asia Pacific region also showed evidence of GEM outflow (Friedli et al., 2004). GEM emitted in China and East Asian countries can undergo intercontinental transport as suggested by the GEM / CO ratio measured at Mt. Bachelor Observatory (MBO) in the Pacific Northwest of the USA (Jaffe et al., 2005; Weiss-Penzias et al., 2006; Strode et al., 2008; Timonen et al., 2013). The trans-Pacific transport of $\mathrm{Hg}$ mainly occurred in spring and episodically resulted in a $10-40 \%$ increase in GEM at the monitoring sites in North America (Jaffe et al., 2005; Weiss-Penzias et al., 2006; Durnford et al., 2010).

\subsection{Atmospheric $\mathrm{Hg}$ deposition in China}

The deposition fluxes of $\mathrm{THg}$ and methyl mercury ( $\mathrm{MeHg}$ ) via precipitation, throughfall, and litterfall measured in China are presented in Table 3. The mean $\mathrm{THg}$ and $\mathrm{MeHg}$ concentrations in rainwater collected by wet-only precipitation collectors at remote sites ranged from 3.0 to $4.8 \mathrm{ng} \mathrm{L}^{-1}$ (mean $\left.=4.0 \mathrm{ng} \mathrm{L}^{-1}, n=4\right)$ and from 0.03 to $0.04 \mathrm{ng} \mathrm{L}^{-1}$ (mean $=0.04 \mathrm{ng} \mathrm{L}^{-1}, n=2$ ), respectively. Such aqueous $\mathrm{THg}$ and $\mathrm{MeHg}$ concentrations were much higher in urban areas, with mean values in the ranges of 13.3-52.9 $\mathrm{ng} \mathrm{L}^{-1}$ (mean $=31.2 \mathrm{ng} \mathrm{L}^{-1}, n=5$ ) and 0.05 $0.31 \mathrm{ng} \mathrm{L}^{-1}$ (mean $=0.18 \mathrm{ng} \mathrm{L}^{-1}, n=2$ ), respectively. The $\mathrm{THg}$ and $\mathrm{MeHg}$ concentrations in rainwater collected by bulk precipitation collectors at remote sites of China were much higher than those using wet-only precipitation collectors (Table 3). Some of the bulk precipitation samples were collected at locations close to anthropogenic $\mathrm{Hg}$ sources and on a monthly basis (Guo et al., 2008; Fu et al., 2008b; Wan et al., $2009 \mathrm{~b}$ ), and therefore dry deposition of TPM and GOM can also contribute to the measured wet deposition. Wet-only deposition fluxes of THg and $\mathrm{MeHg}$ were $1.8-7.0 \mu \mathrm{g} \mathrm{m}^{-2} \mathrm{yr}^{-1}$ (mean $=5.1 \mu \mathrm{g} \mathrm{m}^{-2} \mathrm{yr}^{-1}, n=4$ ) and $0.01-0.06 \mu \mathrm{g} \mathrm{m}^{-2} \mathrm{yr}^{-1}$ (mean $=0.04 \mu \mathrm{g} \mathrm{m}^{-2} \mathrm{yr}^{-1}, n=2$ ) at remote sites, and 13.4$56.5 \mu \mathrm{g} \mathrm{m}^{-2} \mathrm{yr}^{-1} \quad\left(\right.$ mean $\left.=31.9 \mu \mathrm{g} \mathrm{m}^{-2} \mathrm{yr}^{-1}, \quad n=4\right)$ and $0.05-0.28 \mu \mathrm{g} \mathrm{m}^{-2} \mathrm{yr}^{-1}\left(\right.$ mean $\left.=0.16 \mu \mathrm{g} \mathrm{m}^{-2} \mathrm{yr}^{-1}, n=2\right)$ at urban sites, respectively (Table 3 ). Wet deposition fluxes of $\mathrm{THg}$ and $\mathrm{MeHg}$ at urban sites in China were higher compared to those in North America and Europe, but wet deposition fluxes of $\mathrm{THg}$ at remote sites were in the lower range of those observed in North America and Europe (Table 3).

Significant positive correlations were observed between rainwater THg concentrations and PBM concentrations $\left(R^{2}=0.66, p<0.05, N=7\right)$ and between rainwater THg concentrations and GOM concentrations $\left(R^{2}=0.78\right.$, 

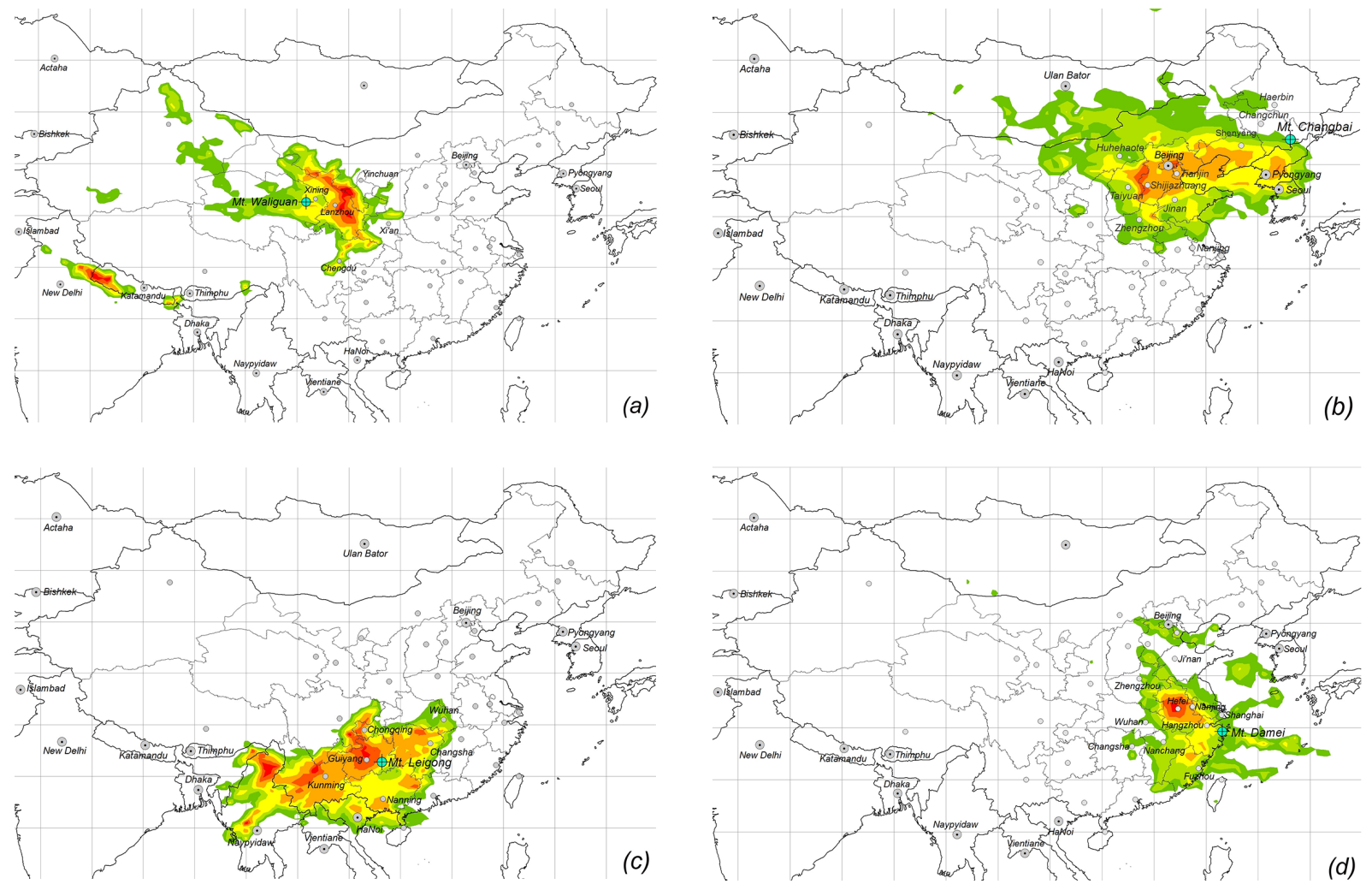

Figure 10. Potential source regions of GEM at (a) Mt. Waliguan, (b) Mt. Changbai, (c) Mt. Leigong, and (d) Mt. Damei (Fu et al., 2010b; Fu et al., 2012a; Fu et al., 2012b; Yu et al., 2015).

$p<0.05, N=6$ ), resulting in the positive correlations between wet deposition fluxes and PBM $\left(R^{2}=0.69, p<0.05\right.$, $N=7)$ and GOM concentrations $\left(R^{2}=0.92, p<0.01\right.$, $N=6$ ). This indicates that washout of PBM and GOM during rain events contributes to $\mathrm{Hg}$ wet deposition in China. Such a contribution is particularly important in urban areas where PBM and GOM concentrations are highly elevated. In remote areas of China, however, washout of elevated atmospheric PBM does not seem to drive a notable increase in $\mathrm{Hg}$ wet deposition flux. This is likely because of the low washout rate of PBM during rain events (Lee et al., 2001; Seigneur et al., 2004). Also, most of the remote sites were at high altitude with low-level clouds, which reduced the contribution of $\mathrm{Hg}$ washout.

Study of dry deposition of $\mathrm{Hg}$ is of special importance for constructing the regional and global mass budget of $\mathrm{Hg}$. Lin et al. (2010) simulated the dry deposition of $\mathrm{Hg}$ in East Asia using the CMAQ-Hg model. The results demonstrated a remarkable spatial distribution of dry deposition fluxes ranging from 10 to $150 \mu \mathrm{g} \mathrm{m}^{-2} \mathrm{yr}^{-1}$. The greatest deposition fluxes were found to be related to emission sources in the major urban areas of China (Lin et al., 2010). Dry deposition of $\mathrm{Hg}$ was also estimated in forest areas of China by subtracting wet deposition flux measured in open areas from the sum of deposition via throughfall and lit- terfall (Table 3). Using this approach, annual deposition flux in Tieshanping forest near the megacity of Chongqing was estimated to be $262 \mu \mathrm{g} \mathrm{m}^{-2} \mathrm{yr}^{-1}$ (Wang et al., 2009), which is of the same order of magnitude compared to the model-predicted deposition. At the remote Mt. Gongga and Mt. Leigong forest in southwestern China, annual dry deposition fluxes reached 66.5 and $43.9 \mu \mathrm{g} \mathrm{m}^{-2} \mathrm{yr}^{-1}$, respectively (Fu et al., 2010a, 2010b). Such dry deposition fluxes were 1.8-13.6 times the reported dry deposition fluxes in North America (range 13.3-34.0 $\mu \mathrm{g} \mathrm{m}^{-2} \mathrm{yr}^{-1}$, mean $=19.2 \mu \mathrm{g} \mathrm{m}^{-2} \mathrm{yr}^{-1}, n=5$ ) and Europe (range 25.3$36.0 \mu \mathrm{g} \mathrm{m}^{-2} \mathrm{yr}^{-1}$, mean $=29.6 \mu \mathrm{g} \mathrm{m}^{-2} \mathrm{yr}^{-1}, n=5$ ) (Lee et al., 2000; Grigal et al., 2000; Rea et al., 2001; St Louis et al., 2001; Lindberg et al., 2007). The much greater dry deposition of $\mathrm{Hg}$ in China was likely due to the elevated GEM and PBM concentrations that enhance the accumulation of $\mathrm{Hg}$ in leaves and on foliage surfaces (St Louis et al., 2001; Frescholtz et al., 2003). Dry deposition contributes $72-90 \%$ of total $\mathrm{Hg}$ deposition in forest areas of China, consistent with the results predicted by modeling studies that dry deposition is the predominant removal pathway of atmospheric $\mathrm{Hg}$ ( $\mathrm{Lin}$ et al., 2010; L. Wang et al., 2014). 
Table 3. Hg concentrations and deposition fluxes in precipitation, throughfall, and litterfall in China and other regions.

\begin{tabular}{|c|c|c|c|c|c|c|c|c|c|c|c|}
\hline \multirow{3}{*}{ Site } & \multicolumn{3}{|c|}{ Location } & \multirow{3}{*}{ Type } & \multirow{3}{*}{ Study period } & \multirow{3}{*}{ Samples } & \multirow{2}{*}{\multicolumn{2}{|c|}{$\begin{array}{l}\mathrm{Hg} \text { concentration } \\
\left(\mathrm{ng} \mathrm{L}^{-1} \text { or } \mathrm{ng} \mathrm{g}^{-1}\right)\end{array}$}} & \multirow{2}{*}{\multicolumn{2}{|c|}{$\begin{array}{l}\text { Deposition flux } \\
\left(\mu \mathrm{g} \mathrm{m}^{-2} \mathrm{yr}^{-1}\right)\end{array}$}} & \multirow{3}{*}{ References } \\
\hline & \multirow[t]{2}{*}{ Lon } & \multirow[t]{2}{*}{ Lat } & \multirow{2}{*}{$\begin{array}{l}\text { Altitude } \\
(\mathrm{m} \text { a.s. } 1)\end{array}$} & & & & & & & & \\
\hline & & & & & & & $\mathrm{THg}$ & $\mathrm{MeHg}$ & $\mathrm{THg}$ & $\mathrm{MeHg}$ & \\
\hline Mt. Ailao, Yunnan & 101.02 & 24.53 & 2500 & Remote & $06 / 2011-05 / 2012$ & $\begin{array}{r}\text { Precipitation } \\
\text { Litterfall }\end{array}$ & $\begin{array}{r}3.0 \\
54.0\end{array}$ & & $\begin{array}{r}5.4 \\
71.2\end{array}$ & & Zhou et al. (2013) \\
\hline Mt. Leigong, Guizhou & 108.20 & 26.39 & 2178 & Remote & 05/2008-05/2009 & $\begin{array}{r}\text { Precipitation } \\
\text { Throughfall } \\
\text { Litterfall }\end{array}$ & $\begin{array}{r}4.0 \\
8.9 \\
91.0\end{array}$ & $\begin{array}{r}0.04 \\
0.1 \\
0.48\end{array}$ & $\begin{array}{r}6.1 \\
10.5 \\
39.5\end{array}$ & $\begin{array}{l}0.06 \\
0.12 \\
0.28\end{array}$ & Fu et al. (2010b) \\
\hline Mt. Damei, Zhejiang & 121.57 & 29.63 & 550 & Remote & 08/2012-07/2013 & $\begin{array}{r}\text { Precipitation } \\
\text { Litterfall }\end{array}$ & $\begin{array}{r}4.1 \\
46.6\end{array}$ & & $\begin{array}{r}7.0 \\
26.0\end{array}$ & & Lang (2014) \\
\hline Nam Co, Tibet & 90.99 & 30.77 & 4730 & Remote & 07/2009-07/2011 & Precipitation & 4.8 & 0.03 & 1.75 & 0.01 & Huang et al. (2012) \\
\hline Mt. Gongga $^{1}$, Sichuan & 102.12 & 29.65 & 1640 & Remote & $01-12 / 2006$ & Precipitation* & 9.9 & & 9.1 & & Fu et al. (2008b) \\
\hline Mt. Gongga $^{2}$, Sichuan & 101.93 & 29.58 & 3000 & Remote & 05/2005-04/2005 & $\begin{array}{r}\text { Precipitation* } \\
\text { Throughfall } \\
\text { Litterfall }\end{array}$ & $\begin{array}{l}14.2 \\
40.2 \\
35.7 \\
\end{array}$ & $\begin{array}{r}0.16 \\
0.3\end{array}$ & $\begin{array}{l}26.1 \\
57.1 \\
35.5\end{array}$ & $\begin{array}{l}0.30 \\
0.43\end{array}$ & Fu et al. (2010a) \\
\hline Mt. Changbai, Jilin & 128.47 & 42.40 & 750 & Remote & 08/2005-07/2006 & Precipitation* & 13.4 & & 8.4 & & Wan et al. (2009a) \\
\hline Puding, Guizhou & 105.80 & 26.37 & 1145 & Remote & 08/2005-07/2006 & Precipitation* & 20.6 & 0.18 & 24.8 & 0.22 & Guo et al. (2008) \\
\hline Hongjiadu, Guizhou & 105.85 & 26.88 & 1130 & Remote & $08 / 2005-07 / 2006$ & Precipitation* & 39.4 & 0.18 & 34.7 & 0.16 & Guo et al. (2008) \\
\hline Yinzidu, Guizhou & 106.12 & 26.57 & 1088 & Remote & $08 / 2005-07 / 2006$ & Precipitation* & 35.7 & 0.18 & 38.1 & 0.19 & Guo et al. (2008) \\
\hline Dongfeng, Guizhou & 106.13 & 26.85 & 970 & Remote & 08/2005-07/2006 & Precipitation* & 37.4 & 0.20 & 36.3 & 0.19 & Guo et al. (2008) \\
\hline Wujiangdu, Guizhou & 106.77 & 27.32 & & Remote & $08 / 2005-07 / 2006$ & Precipitation* & 57.1 & 0.25 & 39.6 & 0.17 & Guo et al. (2008) \\
\hline Guiyang & 106.72 & 26.57 & 1040 & Urban & $07-09 / 2008$ & Precipitation & 13.3 & 0.05 & 13.4 & 0.05 & Liu et al. (2011) \\
\hline Xiamen & 118.31 & 24.60 & 50 & Urban & 07/2013-02/2014 & Precipitation & 26.6 & & 30.4 & & Wu (2014) \\
\hline Chongqing & & & & Urban & $06 / 2010-06 / 2011$ & Precipitation & 30.7 & 0.31 & 28.7 & 0.28 & Wang et al. (2012); Y. M. Wang et al. (2014) \\
\hline Tieshanping, Chongqing & 104.68 & 29.63 & 500 & Urban & $03 / 2005-03 / 2006$ & $\begin{array}{r}\text { Precipitation } \\
\text { Throughfall } \\
\text { Litterfall }\end{array}$ & $\begin{array}{r}32.3 \\
69.7 \\
105\end{array}$ & & $\begin{array}{r}29.0 \\
71.3 \\
220\end{array}$ & & Wang et al. (2009) \\
\hline Nanjing & 118.78 & 32.05 & 100 & Urban & $06 / 2011-02 / 2012$ & Precipitation & 52.9 & & 56.5 & & Zhu et al. (2014) \\
\hline North America & & & & Urban & & Precipitation & $7.8-15.0$ & & $8.4-17.2$ & & $\begin{array}{l}\text { Mason et al. (2000); Keeler et al. (2005); } \\
\text { Prestbo and Gay (2009) }\end{array}$ \\
\hline & & & & Remote & & $\begin{array}{r}\text { Precipitation } \\
\text { Throughfall } \\
\text { Litterfall }\end{array}$ & $\begin{array}{r}4.9-22.4 \\
6.6-20.7 \\
32.0-57.0\end{array}$ & $\begin{array}{r}0.12 \\
0.22 \\
0.06-0.55\end{array}$ & $\begin{array}{l}2.5-21.5 \\
1.6-12.0 \\
7.2-15.0\end{array}$ & $\begin{array}{r}0.09 \\
0.09 \\
0.01-0.24\end{array}$ & $\begin{array}{l}\text { Rea et al. (2001); St Louis et al. (2001); } \\
\text { Demers et al. (2007); Choi et al. (2008); } \\
\text { Prestbo and Gay (2009); Fisher and Wolfe (2012) }\end{array}$ \\
\hline Europe & & & & Remote & & $\begin{array}{r}\text { Precipitation } \\
\text { Throughfall } \\
\text { Litterfall }\end{array}$ & $\begin{array}{l}11.9-18.0 \\
22.8-29.0 \\
28.0-68.0\end{array}$ & & $\begin{array}{r}7.0-36.0 \\
15.0-39.0 \\
4.0-32.5\end{array}$ & & $\begin{array}{l}\text { Munthe et al. (1995); Lee et al. (2000); } \\
\text { Schwesig and Matzner (2000); } \\
\text { Wangberg et al. (2007); Larssen et al. (2008) }\end{array}$ \\
\hline
\end{tabular}

(Precipitation: ${ }^{*}$ indicates bulk precipitation and the rest indicate wet-only precipitation. Mt. Gongga: ${ }^{1}$ elevation of the sampling site was $1600 \mathrm{~m}$ above sea level.

2 Elevation of the sampling site was $3000 \mathrm{~m}$ above sea level).

\subsection{Limitations, implications and research needs}

Although the methods used in quantifying mercury concentrations and forms have significant uncertainties as discussed in Sect. 2.2, the relative magnitudes of GEM and PBM concentrations measured using similar analytical protocols (Tekran speciation method) at remote and urban sites in China were substantially higher than the background concentrations in the Northern Hemisphere, which provide evidence of the influence of anthropogenic and natural $\mathrm{Hg}$ emissions in China and neighboring countries. Many issues and knowledge gaps exist and deserve further study.

First, there is no coordinated observational network for atmospheric $\mathrm{Hg}$ in China. In North America and Europe, much effort has been made to establish global or continental observational networks including the Global Mercury Observation System (GMOS), American Atmospheric Mercury Network (AMNet), Canadian Atmospheric Mercury Network (CAMNet) and Mercury Deposition Network (MDN). The network observations have been integrated with modeling studies, leading to improved understanding of $\mathrm{Hg}$ fate and transport.

The geographical differences in atmospheric compositions (e.g., different levels of air pollutants) provide an opportunity to investigate $\mathrm{Hg}$ behavior in air under different atmospheric conditions. Air pollution has become a major problem in China. Previous studies have shown that the concentrations of aerosols, sulfur dioxide $\left(\mathrm{SO}_{2}\right)$, nitrogen dioxide $\left(\mathrm{NO}_{2}\right)$ and ozone in the atmosphere were higher in China relative to other regions in the Northern Hemisphere (Burrows et al., 1999; Savage et al., 2004; van Donkelaar et al., 2010). These pollutants play important roles in the physicochemical processes in the atmosphere and can affect the fate of atmospheric Hg. Previous studies have shown that gas-particle partitioning of atmospheric GOM and heterogeneous oxidation of GEM at aerosol surfaces facilitate PBM formation (Lindberg et al., 2002; Sprovieri et al., 2005; Amos et al., 2012), which may deplete GEM and GOM and contribute to the elevated PBM concentrations in China. However, there were a few studies that provided detailed assessments of the 
effect of aerosol and other air pollutants on the transformation and wet and dry deposition of atmospheric $\mathrm{Hg}$ in China.

GEM concentrations in China are highly elevated and can enhance the uptake of GEM by vegetation. Such uptake may represent an important sink of atmospheric $\mathrm{Hg}$ in China. Deposition fluxes through litterfall and throughfall at several forest sites in China were found to be much higher than magnitudes in North America and Europe. There is a growing amount of evidence that $\mathrm{Hg}$ found in vegetation biomass does not likely result from the uptake in the root zone followed by upward translocation to stem and leaves (Frescholtz et al., 2003; Cui et al., 2014), which points to the importance of atmospheric uptake in $\mathrm{Hg}$ accumulation in vegetative biomass. We therefore hypothesize that the high $\mathrm{Hg}$ deposition through litterfall and throughfall is a result of the elevated atmospheric GEM and PBM concentrations that drive the uptake and accumulation of $\mathrm{Hg}$ in vegetative biomass, and that $\mathrm{Hg}$ uptake by vegetation is a major sink for removing different $\mathrm{Hg}$ forms from the atmosphere in China. One area of data deficiency is the lack of deposition data over other vegetation coverages such as grass and crop. Garland and cropland are dominant terrestrial ecosystems in China that cover $3.9 \times 10^{6}$ and $1.6 \times 10^{6} \mathrm{~km}^{2}$ of land area, respectively. It is therefore needed to quantify their roles in the removal of atmospheric $\mathrm{Hg}$ in China.

As a persistent air pollutant, the outflow of GEM in China will have an impact on the global $\mathrm{Hg}$ concentration and deposition. Signals of $\mathrm{Hg}$ emissions in China have been detected at receptors in Korea, Japan, the Pacific Northwest and western North America (Weiss-Penzias et al., 2007; Swartzendruber et al., 2008; Jaffe et al., 2005; Nguyen et al., 2010). Model results also suggest that $\mathrm{Hg}$ emissions in Asia enhanced $\mathrm{Hg}$ concentration and deposition elsewhere (Seigneur et al., 2004; Durnford et al., 2010). As more measurement data in China become available, further research efforts should be made to reconcile the observational and model results. Although earlier modeling studies have utilized $\mathrm{Hg}$ observations in China and other Asian regions to construct the mass budget for estimate of $\mathrm{Hg}$ outflow from East Asia, there is a systematic discrepancy in the magnitude and distribution of concentration and dry deposition between the observational and model results (Lin et al., 2010; L. Wang et al., 2014; Song et al., 2015). Such mismatch may be caused by a combination of reasons including the uncertain $\mathrm{Hg}$ emission estimate and the incomplete understanding of physical and chemical transformation, wet and dry deposition of atmospheric $\mathrm{Hg}$ in China. Atmospheric composition in China is different from that of a typical airshed because of the heavy emission loading of $\mathrm{PM}, \mathrm{SO}_{2}, \mathrm{NO}_{x}$, and ozone precursors, which may result in complex atmospheric processes that are not yet understood. Also, Hg dry deposition to vegetation was enhanced due to the generally elevated GEM concentrations, and such an enhanced uptake process has not been implemented in atmospheric $\mathrm{Hg}$ models. More studies should focus on the transformation and removal of at- mospheric $\mathrm{Hg}$ in China, which will help understand the impact of $\mathrm{Hg}$ emission in China on global $\mathrm{Hg}$ pollution.

Continuous, long-term observations of atmospheric $\mathrm{Hg}$ in China should be carried out to assess the temporal change of the atmospheric $\mathrm{Hg}$ burden. Preliminary assessment of GEM concentrations in China points to an increase corresponding to the increase in the regional emission inventory. This finding is in contrast to most observations in remote sites in the Northern Hemisphere (Slemr et al., 2011; Cole et al., 2013). More data that allow analysis of the long-term trend of GEM in China and other Asian countries are needed because (1) the long-term trend of GEM concentrations may not share a similar pattern throughout the Northern Hemisphere, and (2) regional emission influence may exceed the influence of atmospheric circulation of global emissions. In addition, the observed long-term trend should be carefully verified with regional and global modeling assessment to understand the role of $\mathrm{Hg}$ emission in China in the global background of atmospheric Hg. Furthermore, the impact of ongoing efforts of $\mathrm{Hg}$ emission reduction in China caused by the co-benefits of air pollution control devices as well as targeted $\mathrm{Hg}$ emission control, in response to the adoption of the Minamata Convention on Mercury, should be thoroughly investigated to better understand the associated benefit to global $\mathrm{Hg}$ biogeochemical cycling.

\section{Conclusions}

As the largest atmospheric $\mathrm{Hg}$ source region in the world, much attention has been paid to understanding the characteristics and behavior of atmospheric $\mathrm{Hg}$ in China. This paper provides an integrated review of these understandings presented in peer-reviewed literature. GEM and PBM have been found to be substantially elevated in both remote and urban areas of China compared to those observed in North America and Europe. A strong spatial variation in GEM and PBM concentrations was observed, with high concentrations related to regional anthropogenic $\mathrm{Hg}$ emissions in central and eastern China. Annual GEM emission in China was estimated to be 632-1138t over the past decade using reported GEM / CO correlation slopes and emissions of $\mathrm{CO}$ in China, agreeing with the results of reverse modeling but higher than published values estimated from emission activity statistics. Existing field measurements suggested an increase in GEM concentrations at a remote site and an urban site in China over recent years, opposite to reported long-term trend in Europe and North America. The increasing trend in China is possibly caused by the increase in anthropogenic $\mathrm{Hg}$ emissions in the past decade, and indicates that the influence of regional emissions on GEM levels in China exceed global emission influence. GEM concentrations in China displayed two distinct seasonal patterns driven by monsoonal climate that governs the transport of anthropogenic $\mathrm{Hg}$ emissions in China and in neighboring countries. Wet deposition fluxes of $\mathrm{Hg}$ in remote 
areas of China were not significantly higher than the values observed in the rest of the world, while the dry deposition as measured through litterfall and by model simulation was highly elevated compared to those observed in Europe and North America. This indicates that dry deposition of $\mathrm{Hg}$ is likely the dominant pathway for removing atmospheric $\mathrm{Hg}$ in China. However, further studies are needed to better quantify dry deposition of atmospheric $\mathrm{Hg}$ and to improve our understanding of the atmospheric $\mathrm{Hg}$ budget in China, as well as to elucidate the impact of $\mathrm{Hg}$ emission changes on global $\mathrm{Hg}$ pollution.

Acknowledgements. This work was funded by the National 973 Program of China (2013CB430003) and the National Science Foundation of China (41473025, 41273145, 41428301). We also acknowledge Lei Zhang, Shuxiao Wang, Tijian Wang, and Laiguo Chen for providing the diel and monthly mean atmospheric gaseous mercury concentrations at Miyun, Nanjing, Mt. Dinghu, and Guangzhou.

Edited by: R. Ebinghaus

\section{References}

AMAP/UNEP: Technical Background Report for the Global Mercury Assessment 2013, Arctic Monitoring and Assessment Programme, Oslo, Norway/UNEP Chemicals Branch, Geneva, Switzerland, 1-263, 2013.

Ambrose, J. L., Lyman, S. N., Huang, J. Y., Gustin, M. S., and Jaffe, D. A.: Fast Time Resolution Oxidized Mercury Measurements during the Reno Atmospheric Mercury Intercomparison Experiment (RAMIX), Environ. Sci. Technol., 47, 7285-7294, doi:10.1021/Es303916v, 2013.

Amos, H. M., Jacob, D. J., Holmes, C. D., Fisher, J. A., Wang, Q., Yantosca, R. M., Corbitt, E. S., Galarneau, E., Rutter, A. P., Gustin, M. S., Steffen, A., Schauer, J. J., Graydon, J. A., Louis, V. L. St., Talbot, R. W., Edgerton, E. S., Zhang, Y., and Sunderland, E. M.: Gas-particle partitioning of atmospheric $\mathrm{Hg}(\mathrm{II})$ and its effect on global mercury deposition, Atmos. Chem. Phys., 12, 591-603, doi:10.5194/acp-12-591-2012, 2012.

An, Z. S.: The history and variability of the East Asian paleomonsoon climate, Quaternary Sci. Rev., 19, 171-187, doi:10.1016/S0277-3791(99)00060-8, 2000.

Brooks, S., Luke, W., Cohen, M., Kelly, P., Lefer, B., and Rappengluck, B.: Mercury species measured atop the Moody Tower TRAMP site, Houston, Texas, Atmos. Environ., 44, 4045-4055, doi:10.1016/j.atmosenv.2009.02.009, 2010.

Burrows, J. P., Weber, M., Buchwitz, M., Rozanov, V., LadstatterWeissenmayer, A., Richter, A., DeBeek, R., Hoogen, R., Bramstedt, K., Eichmann, K. U., and Eisinger, M.: The global ozone monitoring experiment (GOME): Mission concept and first scientific results, J. Atmos. Sci., 56, 151-175, doi:10.1175/15200469(1999)056< 0151:Tgomeg> 2.0.Co; 2, 1999.

Chen, L. G., Liu, M., Xu, Z. C., Fan, R. F., Tao, J., Chen, D. H., Zhang, D. Q., Xie, D. H., and Sun, J. R.: Variation trends and influencing factors of total gaseous mercury in the Pearl
River Delta-A highly industrialised region in South China influenced by seasonal monsoons, Atmos. Environ., 77, 757-766, doi:10.1016/j.atmosenv.2013.05.053, 2013.

Choi, E. M., Kim, S. H., Holsen, T. M., and Yi, S. M.: Total gaseous concentrations in mercury in Seoul, Korea: Local sources compared to long-range transport from China and Japan, Environ. Pollut., 157, 816-822, doi:10.1016/j.envpol.2008.11.023, 2009.

Choi, H. D., Sharac, T. J., and Holsen, T. M.: Mercury deposition in the Adirondacks: A comparison between precipitation and throughfall, Atmos. Environ., 42, 1818-1827, doi:10.1016/j.atmosenv.2007.11.036, 2008.

Ci, Z. J., Zhang, X. S., Wang, Z. W., and Niu, Z. C.: Atmospheric gaseous elemental mercury (GEM) over a coastal/rural site downwind of East China: Temporal variation and long-range transport, Atmos. Environ., 45, 2480-2487, doi:10.1016/j.atmosenv.2011.02.043, 2011a.

Ci, Z. J., Zhang, X. S., Wang, Z. W., Niu, Z. C., Diao, X. Y., and Wang, S. W.: Distribution and air-sea exchange of mercury (Hg) in the Yellow Sea, Atmos. Chem. Phys., 11, 2881-2892, doi:10.5194/acp-11-2881-2011, $2011 \mathrm{~b}$.

Cole, A. S., Steffen, A., Pfaffhuber, K. A., Berg, T., Pilote, M., Poissant, L., Tordon, R., and Hung, H.: Ten-year trends of atmospheric mercury in the high Arctic compared to Canadian subArctic and mid-latitude sites, Atmos. Chem. Phys., 13, 15351545, doi:10.5194/acp-13-1535-2013, 2013.

Cui, L. W., Feng, X. B., Lin, C. J., Wang, X. M., Meng, B., Wang, X., and Wang, H.: Accumulation and Translocation of (198)Hg in Four Crop Species, Environ. Toxicol. Chem., 33, 334-340, doi:10.1002/Etc.2443, 2014.

Demers, J. D., Driscoll, C. T., Fahey, T. J., and Yavitt, J. B.: Mercury cycling in litter and soil in different forest types in the Adirondack region, New York, USA, Ecol. Appl., 17, 13411351, doi:10.1890/06-1697.1, 2007.

Dommergue, A., Ferrari, C. P., Planchon, F. A. M., and Boutron, C. F.: Influence of anthropogenic sources on total gaseous mercury variability in grenoble suburban air (France), Sci. Total Environ., 297, 203-213, doi:10.1016/S0048-9697(02)00133-X, 2002.

Dommergue, A., Sprovieri, F., Pirrone, N., Ebinghaus, R., Brooks, S., Courteaud, J., and Ferrari, C. P.: Overview of mercury measurements in the Antarctic troposphere, Atmos. Chem. Phys., 10, 3309-3319, doi:10.5194/acp-10-3309-2010, 2010.

Dou, H. Y., Wang, S. X., Wang, L., Zhang, L., and Hao, J. M.: Characteristics of total gaseous mercury concentrations at a rural site of Yangtze Delta, China, Environ. Sci., 34, 1-7, 2013 (in Chinese).

Driscoll, C. T., Mason, R. P., Chan, H. M., Jacob, D. J., and Pirrone, N.: Mercury as a Global Pollutant: Sources, Pathways, and Effects, Environ. Sci. Technol., 47, 4967-4983, doi:10.1021/Es305071v, 2013.

Duan, X. Q. and Yang, H.: Pollutions of tmospheric partilucated mercury in urban Lanzhou, Environ. Monitor. Technol., 7, 1920, 1995 (in Chinese).

Durnford, D., Dastoor, A., Figueras-Nieto, D., and Ryjkov, A.: Long range transport of mercury to the Arctic and across Canada, Atmos. Chem. Phys., 10, 6063-6086, doi:10.5194/acp-10-60632010, 2010.

Ebinghaus, R., Jennings, S. G., Schroeder, W. H., Berg, T., Donaghy, T., Guentzel, J., Kenny, C., Kock, H. H., Kvietkus, K., Landing, W., Muhleck, T., Munthe, J., Prestbo, E. M., Schnee- 
berger, D., Slemr, F., Sommar, J., Urba, A., Wallschlager, D., and Xiao, Z.: International field intercomparison measurements of atmospheric mercury species at Mace Head, Ireland, Atmos. Environ., 33, 3063-3073, doi:10.1016/S1352-2310(98)00119-8, 1999.

Ebinghaus, R., Kock, H. H., Coggins, A. M., Spain, T. G., Jennings, S. G., and Temme, C.: Long-term measurements of atmospheric mercury at Mace Head, Irish west coast, between 1995 and 2001, Atmos. Environ., 36, 5267-5276, doi:10.1016/S13522310(02)00691-X, 2002.

Engle, M. A., Tate, M. T., Krabbenhoft, D. P., Schauer, J. J., Kolker, A., Shanley, J. B., and Bothner, M. H.: Comparison of atmospheric mercury speciation and deposition at nine sites across central and eastern North America, J. Geophys. Res.-Atmos., 115, D18306, doi:10.1029/2010jd014064, 2010.

Faïn, X., Obrist, D., Hallar, A. G., Mccubbin, I., and Rahn, T.: High levels of reactive gaseous mercury observed at a high elevation research laboratory in the Rocky Mountains, Atmos. Chem. Phys., 9, 8049-8060, doi:10.5194/acp-9-8049-2009, 2009.

Fang, F. M., Wang, Q. C., and Li, J. F.: Urban environmental mercury in Changchun, a metropolitan city in Northeastern China: source, cycle, and fate, Sci. Total Environ., 330, 159-170, doi:10.1016/j.scitotenv.2004.04.006, 2004.

Feng, X. B., Shang, L. H., Wang, S. F., Tang, S. L., and Zheng, W.: Temporal variation of total gaseous mercury in the air of Guiyang, China, J. Geophys. Res.-Atmos., 109, D03303, doi:10.1029/2003jd004159, 2004.

Feng, X. B., Wang, S. F., Qiu, G. A., Hou, Y. M., and Tang, S. L.: Total gaseous mercury emissions from soil in Guiyang, Guizhou, China, J. Geophys. Res.-Atmos., 110, D14306, doi:10.1029/2004jd005643, 2005.

Fisher, L. S. and Wolfe, M. H.: Examination of mercury inputs by throughfall and litterfall in the Great Smoky Mountains National Park, Atmos. Environ., 47, 554-559, doi:10.1016/j.atmosenv.2011.10.017, 2012.

Frescholtz, T. F., Gustin, M. S., Schorran, D. E., and Fernandez, G. C. J.: Assessing the source of mercury in foliar tissue of quaking aspen, Environ. Toxicol. Chem., 22, 2114 2119, doi:10.1897/1551-5028(2003)022<2114:Atsomi> 2.0.Co; 2, 2003.

Friedli, H. R., Radke, L. F., Prescott, R., Li, P., Woo, J. H., and Carmichael, G. R.: Mercury in the atmosphere around Japan, Korea, and China as observed during the 2001 ACEAsia field campaign: Measurements, distributions, sources, and implications, J. Geophys. Res.-Atmos., 109, D19s25, doi:10.1029/2003jd004244, 2004.

Friedli, H. R., Arellano Jr., A. F., Geng, F., Cai, C., and Pan, L.: Measurements of atmospheric mercury in Shanghai during September 2009, Atmos. Chem. Phys., 11, 3781-3788, doi:10.5194/acp-11-3781-2011, 2011.

Fu, X. W. and Feng, X. B.: Variations of atmospheric total gaseous mercury concentrations for the sampling campaigns of 2001/2002 and 2009/2010 and implications of changes in regional emissions of atmospheric mercury, Bull Miner Petr Geochem, 34, 242-249, 2015 (in Chinese).

Fu, X. W., Feng, X. B., Zhu, W. Z., Wang, S. F., and Lu, J. L.: Total gaseous mercury concentrations in ambient air in the eastern slope of Mt. Gongga, South-Eastern fringe of the Tibetan plateau, China, Atmos. Environ., 42, 970-979, doi:10.1016/j.atmosenv.2007.10.018, 2008a.

Fu, X. W., Feng, X. B., Zhu, W. Z., Zheng, W., Wang, S. F., and Lu, J. Y.: Total particulate and reactive gaseous mercury in ambient air on the eastern slope of the Mt. Gongga area, China, Appl. Geochem., 23, 408-418, doi:10.1016/j.apgeochem.2007.12.018, 2008b.

Fu, X. W., Feng, X., Zhu, W., Rothenberg, S., Yao, H., and Zhang, H.: Elevated atmospheric deposition and dynamics of mercury in a remote upland forest of southwestern China, Environ. Pollut., 158, 2324-2333, doi:10.1016/j.envpol.2010.01.032, 2010a.

Fu, X. W., Feng, X., Dong, Z. Q., Yin, R. S., Wang, J. X., Yang, Z. R., and Zhang, H.: Atmospheric gaseous elemental mercury (GEM) concentrations and mercury depositions at a high-altitude mountain peak in south China, Atmos. Chem. Phys., 10, 24252437, doi:10.5194/acp-10-2425-2010, 2010b.

Fu, X. W., Feng, X. B., Zhang, G., Xu, W. H., Li, X. D., Yao, H., Liang, P., Li, J., Sommar, J., Yin, R. S., and Liu, N.: Mercury in the marine boundary layer and seawater of the South China Sea: Concentrations, sea/air flux, and implication for land outflow, J. Geophys. Res.-Atmos., 115, D06303, doi:10.1029/2009jd012958, 2010c.

Fu, X. W., Feng, X. B., Qiu, G. L., Shang, L. H., and Zhang, H.: Speciated atmospheric mercury and its potential source in Guiyang, China, Atmos. Environ., 45, 4205-4212, doi:10.1016/j.atmosenv.2011.05.012, 2011a.

Fu, X. W., Feng, X. B., and Zhang, H.: Atmospheric total gaseous mercury concentration in Guiyang: measurements intercomparison with Lumex Ra-915AM and Tekran 2537A, Chinese J. Ecol., 30, 939-943, 2011b (in Chinese)

Fu, X. W., Feng, X., Liang, P., Deliger, Zhang, H., Ji, J., and Liu, P.: Temporal trend and sources of speciated atmospheric mercury at Waliguan GAW station, Northwestern China, Atmos. Chem. Phys., 12, 1951-1964, doi:10.5194/acp-12-1951-2012, 2012a.

Fu, X. W., Feng, X., Shang, L. H., Wang, S. F., and Zhang, H.: Two years of measurements of atmospheric total gaseous mercury (TGM) at a remote site in Mt. Changbai area, Northeastern China, Atmos. Chem. Phys., 12, 4215-4226, doi:10.5194/acp12-4215-2012, 2012b.

Fu, X. W., Feng, X. B., Sommar, J., and Wang, S. F.: A review of studies on atmospheric mercury in China, Sci. Total Environ., 421, 73-81, doi:10.1016/j.scitotenv.2011.09.089, 2012c.

Fu, X. W., Zhang, H., Feng, X. B., and Zhu, W.: Speciated atmospheric mercury in rural Mt. Changbai, northeast China, 17 th internatial conference of heavy metals in the environment, Guiyang, China, 22-25 September, 219-219, 2014.

Fu, X. W., Zhang, H., Lin, C.-J., Feng, X. B., Zhou, L. X., and Fang, S. X.: Correlation slopes of GEM / CO, GEM / $\mathrm{CO}_{2}$, and GEM $/ \mathrm{CH}_{4}$ and estimated mercury emissions in China, South Asia, the Indochinese Peninsula, and Central Asia derived from observations in northwestern and southwestern China, Atmos. Chem. Phys., 15, 1013-1028, doi:10.5194/acp-15-1013-2015, 2015.

Gardfeldt, K., Sommar, J., Ferrara, R., Ceccarini, C., Lanzillotta, E., Munthe, J., Wangberg, I., Lindqvist, O., Pirrone, N., Sprovieri, F., Pesenti, E., and Stromberg, D.: Evasion of mercury from coastal and open waters of the Atlantic Ocean and the Mediterranean Sea, Atmos. Environ., 37, S73-S84, doi:10.1016/S13522310(03)00238-3, 2003. 
Grigal, D. F., Kolka, R. K., Fleck, J. A., and Nater, E. A.: Mercury budget of an upland-peatland watershed, Biogeochemistry, 50, 95-109, doi:10.1023/A:1006322705566, 2000.

Guo, Y. N., Feng, X. B., Li, Z. G., He, T. R., Yan, H. Y., Meng, B., Zhang, J. F., and Qiu, G. L.: Distribution and wet deposition fluxes of total and methyl mercury in Wujiang River Basin, Guizhou, China, Atmos. Environ., 42, 7096-7103, doi:10.1016/j.atmosenv.2008.06.006, 2008.

Gustin, M., and Jaffe, D.: Reducing the Uncertainty in Measurement and Understanding of Mercury in the Atmosphere, Environ. Sci. Technol., 44, 2222-2227, doi:10.1021/Es902736k, 2010.

Gustin, M. S., Lindberg, S. E., and Weisberg, P. J.: An update on the natural sources and sinks of atmospheric mercury, Appl. Geochem., 23, 482-493, doi:10.1016/j.apgeochem.2007.12.010, 2008.

Gustin, M. S., Huang, J. Y., Miller, M. B., Peterson, C., Jaffe, D. A., Ambrose, J., Finley, B. D., Lyman, S. N., Call, K., Talbot, R., Feddersen, D., Mao, H. T., and Lindberg, S. E.: Do We Understand What the Mercury Speciation Instruments Are Actually Measuring? Results of RAMIX, Environ. Sci. Technol., 47, 7295-7306, doi:10.1021/Es3039104, 2013.

Gustin, M. S., Amos, H. M., Huang, J., Miller, M. B., and Heidecorn, K.: Measuring and modeling mercury in the atmosphere: a critical review, Atmos. Chem. Phys., 15, 5697-5713, doi:10.5194/acp-15-5697-2015, 2015.

Hedgecock, I. M. and Pirrone, N.: Chasing Quicksilver:? Modeling the Atmospheric Lifetime of $\mathrm{HgO}(\mathrm{g})$ in the Marine Boundary Layer at Various Latitudes, Environ. Sci. Technol., 38, 69-76, doi:10.1021/es034623z, 2003.

Huang, J., Kang, S. C., Zhang, Q. G., Yan, H. Y., Guo, J. M., Jenkins, M. G., Zhang, G. S., and Wang, K.: Wet deposition of mercury at a remote site in the Tibetan Plateau: Concentrations, speciation, and fluxes, Atmos. Environ., 62, 540-550, doi:10.1016/j.atmosenv.2012.09.003, 2012.

Huang, J. Y., Miller, M. B., Weiss-Penzias, P., and Gustin, M. S.: Comparison of Gaseous Oxidized $\mathrm{Hg}$ Measured by KCl-Coated Denuders, and Nylon and Cation Exchange Membranes, Environ. Sci. Technol., 47, 7307-7316, doi:10.1021/Es4012349, 2013

Jaffe, D., Prestbo, E., Swartzendruber, P., Weiss-Penzias, P., Kato, S., Takami, A., Hatakeyama, S., and Kajii, Y.: Export of atmospheric mercury from Asia, Atmos. Environ., 39, 3029-=3038, doi:10.1016/j.atmosenv.2005.01.030, 2005.

Jaffe, D. A., Lyman, S., Amos, H. M., Gustin, M. S., Huang, J. Y., Selin, N. E., Levin, L., ter Schure, A., Mason, R. P., Talbot, R., Rutter, A., Finley, B., Jaegle, L., Shah, V., McClure, C., Arnbrose, J., Gratz, L., Lindberg, S., Weiss-Penzias, P., Sheu, G. R., Feddersen, D., Horvat, M., Dastoor, A., Hynes, A. J., Mao, H. T., Sonke, J. E., Slemr, F., Fisher, J. A., Ebinghaus, R., Zhang, Y. X., and Edwards, G.: Progress on Understanding Atmospheric Mercury Hampered by Uncertain Measurements, Environ. Sci. Technol., 48, 7204-7206, doi:10.1021/Es5026432, 2014.

Keeler, G., Gratz, L., and Al-Wali, K. I.: Long-term atmospheric mercury wet deposition at Underhill, Vermont, Ecotoxicology, 14, 71-83, 2005.

Kim, K. H., Mishra, V. K., and Hong, S.: The rapid and continuous monitoring of gaseous elemental mercury (GEM) behavior in ambient air, Atmos. Environ., 40, 3281-3293, doi:10.1016/j.atmosenv.2006.01.046, 2006.
Kock, H. H., Bieber, E., Ebinghaus, R., Spain, T. G., and Thees, B.: Comparison of long-term trends and seasonal variations of atmospheric mercury concentrations at the two European coastal monitoring stations Mace Head, Ireland, and Zingst, Germany, Atmos. Environ., 39, 7549-7556, doi:10.1016/j.atmosenv.2005.02.059, 2005.

Lai, S. C., Baker, A. K., Schuck, T. J., Slemr, F., Brenninkmeijer, C. A. M., van Velthoven, P., Oram, D. E., Zahn, A., and Ziereis, H.: Characterization and source regions of 51 high$\mathrm{CO}$ events observed during Civil Aircraft for the Regular Investigation of the Atmosphere Based on an Instrument Container (CARIBIC) flights between south China and the Philippines, 2005-2008, J. Geophys. Res.-Atmos., 116, D20308, doi:10.1029/2011jd016375, 2011.

Lan, X., Talbot, R., Castro, M., Perry, K., and Luke, W.: Seasonal and diurnal variations of atmospheric mercury across the US determined from AMNet monitoring data, Atmos. Chem. Phys., 12, 10569-10582, doi:10.5194/acp-12-10569-2012, 2012.

Landis, M. S. and Keeler, G. J.: Critical evaluation of a modified automatic wet-only precipitation collector for mercury and trace element determinations, Environ. Sci. Technol., 31, 2610-2615, doi:10.1021/Es9700055, 1997.

Landis, M. S., Stevens, R. K., Schaedlich, F., and Prestbo, E. M.: Development and characterization of an annular denuder methodology for the measurement of divalent inorganic reactive gaseous mercury in ambient air, Environ. Sci. Technol., 36, 3000-3009, doi:10.1021/Es015887t, 2002.

Lang, X.: Mercury in atmospheric precipitation and litterfall in Mt.Ailao and Mt.Damei, Master's dissertation, Guizhou University, Guiyang, China, 1-78, 2014 (in Chinese).

Larssen, T., de Wit, H. A., Wiker, M., and Halse, K.: Mercury budget of a small forested boreal catchment in southeast Norway, Sci. Total Environ., 404, 290-296, doi:10.1016/j.scitotenv.2008.03.013, 2008.

Lee, D. S., Dollard, G. J., and Pepler, S.: Gas-phase mercury in the atmosphere of the United Kingdom, Atmos. Environ., 32, 855864, doi:10.1016/S1352-2310(97)00316-6, 1998.

Lee, D. S., Nemitz, E., Fowler, D., and Kingdon, R. D.: Modelling atmospheric mercury transport and deposition across Europe and the UK, Atmos. Environ., 35, 5455=-5466, doi:10.1016/S13522310(01)00284-9, 2001.

Lee, Y. H., Bishop, K. H., and Munthe, J.: Do concepts about catchment cycling of methylmercury and mercury in boreal catchments stand the test of time? Six years of atmospheric inputs and runoff export at Svartberget, northern Sweden, Sci. Total Environ., 260, 11-20, doi:10.1016/S0048-9697(00)00538-6, 2000.

Leermakers, M., Baeyens, W., Ebinghaus, R., Kuballa, J., and Kock, H. H.: Determination of atmospheric mercury during the North Sea experiment, Water Air Soil Poll., 97, 257-263, doi:10.1023/A:1018311107587, 1997.

Li, J., Sommar, J., Wangberg, I., Lindqvist, O., and Wei, S. Q.: Short-time variation of mercury speciation in the urban of Goteborg during GOTE-2005, Atmos. Environ., 42, 8382-8388, doi:10.1016/j.atmosenv.2008.08.007, 2008.

Li, P., Feng, X. B., Qiu, G. L., Shang, L. H., Wang, S. F., and Meng, B.: Atmospheric mercury emission from artisanal mercury mining in Guizhou Province, Southwestern China, Atmos. Environ., 43, 2247-2251, doi:10.1016/j.atmosenv.2009.01.050, 2009. 
Li, Z., Xia, C. H., Wang, X. M., Xiang, Y. R., and Xie, Z. Q.: Total gaseous mercury in Pearl River Delta region, China during 2008 winter period, Atmos. Environ., 45, 834-838, doi:10.1016/j.atmosenv.2010.11.032, 2011.

$\mathrm{Li}, \mathrm{Z}$.: The concentrations, species and influencing factors of atmospheric mercury in the urban and remote areas: A case study of Chinese cities and Arctic Ocean, PH.D. dissertation, Unicersity of Science and Technology of China, Hefei, China, 1-122, 2012 (in Chinese).

Liang, S., Xu, M., Liu, Z., Suh, S., and Zhang, T. Z.: Socioeconomic Drivers of Mercury Emissions in China from 1992 to 2007, Environ. Sci. Technol., 47, 3234-3240, doi:10.1021/Es303728d, 2013.

Lin, C.-J., Pan, L., Streets, D. G., Shetty, S. K., Jang, C., Feng, X., Chu, H.-W., and Ho, T. C.: Estimating mercury emission outflow from East Asia using CMAQ-Hg, Atmos. Chem. Phys., 10, 1853-1864, doi:10.5194/acp-10-1853-2010, 2010.

Lindberg, S., Bullock, R., Ebinghaus, R., Engstrom, D., Feng, X. B., Fitzgerald, W., Pirrone, N., Prestbo, E., and Seigneur, C.: A synthesis of progress and uncertainties in attributing the sources of mercury in deposition, Ambio, 36, 19-32, 2007.

Lindberg, S. E. and Stratton, W. J.: Atmospheric mercury speciation: Concentrations and behavior of reactive gaseous mercury in ambient air, Environ. Sci. Technol., 32, 49-57, doi:10.1021/Es970546u, 1998.

Lindberg, S. E., Brooks, S., Lin, C. J., Scott, K. J., Landis, M. S., Stevens, R. K., Goodsite, M., and Richter, A.: Dynamic oxidation of gaseous mercury in the Arctic troposphere at polar sunrise, Environ. Sci. Technol., 36, 1245-1256, doi:10.1021/Es0111941, 2002.

Liu, B., Keeler, G. J., Dvonch, J. T., Barres, J. A., Lynam, M. M., Marsik, F. J., and Morgan, J. T.: Urban-rural differences in atmospheric mercury speciation, Atmos. Environ., 44, 2013-2023, doi:10.1016/j.atmosenv.2010.02.012, 2010.

Liu, N., Qiu, G. L., Feng, X. B., Landis, M., Fu, X. W., and Shang, L. H.: Distribution characteristics of mercury in precipitation of Guiyang, China, Chinese J. Ecol., 30, 933-938, 2011 (in Chinese).

Liu, S. L., Nadim, F., Perkins, C., Carley, R. J., Hoag, G. E., Lin, Y. H., and Chen, L. T.: Atmospheric mercury monitoring survey in Beijing, China, Chemosphere, 48, 97-107, doi:10.1016/S00456535(02)00026-7, 2002.

Lynam, M. M. and Keeler, G. J.: Comparison of methods for particulate phase mercury analysis: sampling and analysis, Anal. Bioanal. Chem., 374, 1009-1014, doi:10.1007/s00216002-1584-4, 2002.

Lyman, S. N. and Jaffe, D. A.: Formation and fate of oxidized mercury in the upper troposphere and lower stratosphere, Nat. Geosci., 5, 114-117, doi:10.1038/Ngeo1353, 2012.

Lyman, S. N., Jaffe, D. A., and Gustin, M. S.: Release of mercury halides from $\mathrm{KCl}$ denuders in the presence of ozone, Atmos. Chem. Phys., 10, 8197-8204, doi:10.5194/acp-10-81972010, 2010.

Mason, R. P. and Sheu, G. R.: Role of the ocean in the global mercury cycle, Global Biogeochem. Cy., 16, 1093, doi:10.1029/2001gb001440, 2002.

Mason, R. P., Lawson, N. M., and Sheu, G. R.: Annual and seasonal trends in mercury deposition in Maryland, Atmos. Environ., 34, 1691-1701, doi:10.1016/S1352-2310(99)00428-8, 2000.
McClure, C. D., Jaffe, D. A., and Edgerton, E. S.: Evaluation of the KCI Denuder Method for Gaseous Oxidized Mercury using $\mathrm{HgBr} 2$ at an In-Service AMNet Site, Environ. Sci. Technol., 48, 11437-11444, doi:10.1021/Es502545k, 2014.

Minschwaner, K., Manney, G. L., Livesey, N. J., Pumphrey, H. C., Pickett, H. M., Froidevaux, L., Lambert, A., Schwartz, M. J., Bernath, P. F., Walker, K. A., and Boone, C. D.: The photochemistry of carbon monoxide in the stratosphere and mesosphere evaluated from observations by the Microwave Limb Sounder on the Aura satellite, J. Geophys. Res.-Atmos., 115, D13303, doi:10.1029/2009jd012654, 2010.

Moore, C. W., Obrist, D., and Luria, M.: Atmospheric mercury depletion events at the Dead Sea: Spatial and temporal aspects, Atmos. Environ., 69, 231-239, doi:10.1016/j.atmosenv.2012.12.020, 2013.

Müller, D., Wip, D., Warneke, T., Holmes, C. D., Dastoor, A., and Notholt, J.: Sources of atmospheric mercury in the tropics: continuous observations at a coastal site in Suriname, Atmos. Chem. Phys., 12, 7391-7397, doi:10.5194/acp-12-7391-2012, 2012.

Munthe, J., Hultberg, H., and Iverfeldt, A.: Mechanisms of Deposition of Methylmercury and Mercury to Coniferous Forests, Water Air Soil Poll., 80, 363-371, doi:10.1007/Bf01189686, 1995.

Munthe, J., Wangberg, I., Iverfeldt, A., Lindqvist, O., Stromberg, D., Sommar, J., Gardfeldt, K., Petersen, G., Ebinghaus, R., Prestbo, E., Larjava, K., and Siemens, V.: Distribution of atmospheric mercury species in Northern Europe: final results from the MOE project, Atmos. Environ., 37, S9-S20, doi:10.1016/S1352-2310(03)00235-8, 2003.

Murphy, D. M., Thomson, D. S., and Mahoney, T. M. J.: In situ measurements of organics, meteoritic material, mercury, and other elements in aerosols at 5 to 19 kilometers, Science, 282, 1664 1669, doi:10.1126/science.282.5394.1664, 1998.

Nguyen, D. L., Kim, J. Y., Shim, S. G., and Zhang, X. S.: Ground and shipboard measurements of atmospheric gaseous elemental mercury over the Yellow Sea region during 2007-2008, Atmos. Environ., 45, 253-260, doi:10.1016/j.atmosenv.2010.07.021, 2011.

Nguyen, H. T., Kim, M. Y., and Kim, K. H.: The influence of long-range transport on atmospheric mercury on Jeju Island, Korea, Sci. Total Environ., 408, 1295-1307, doi:10.1016/j.scitotenv.2009.10.029, 2010.

Pacyna, E. G., Pacyna, J. M., Fudala, J., Strzelecka-Jastrzab, E., Hlawiczka, S., and Panasiuk, D.: Mercury emissions to the atmosphere from anthropogenic sources in Europe in 2000 and their scenarios until 2020, Sci. Total Environ., 370, 147-156, doi:10.1016/j.scitotenv.2006.06.023, 2006.

Pacyna, E. G., Pacyna, J. M., Sundseth, K., Munthe, J., Kindbom, K., Wilson, S., Steenhuisen, F., and Maxson, P.: Global emission of mercury to the atmosphere from anthropogenic sources in 2005 and projections to 2020, Atmos. Environ., 44, 2487-2499, doi:10.1016/j.atmosenv.2009.06.009, 2010.

Pan, L., Woo, J. H., Carmichael, G. R., Tang, Y. H., Friedli, H. R., and Radke, L. F.: Regional distribution and emissions of mercury in east Asia: A modeling analysis of Asian Pacific Regional Aerosol Characterization Experiment (ACEAsia) observations, J. Geophys. Res.-Atmos., 111, D07109, doi:10.1029/2005jd006381, 2006.

Pan, L., Chai, T. F., Carmichael, G. R., Tang, Y. H., Streets, D., Woo, J. H., Friedli, H. R., and Radke, L. F.: Top-down es- 
timate of mercury emissions in China using four-dimensional variational data assimilation, Atmos. Environ., 41, 2804-2819, doi:10.1016/j.atmosenv.2006.11.048, 2007.

Peterson, C., Gustin, M., and Lyman, S.: Atmospheric mercury concentrations and speciation measured from 2004 to 2007 in Reno, Nevada, USA, Atmos. Environ., 43, 4646-4654, doi:10.1016/j.atmosenv.2009.04.053, 2009.

Pirrone, N., Cinnirella, S., Feng, X., Finkelman, R. B., Friedli, H. R., Leaner, J., Mason, R., Mukherjee, A. B., Stracher, G. B., Streets, D. G., and Telmer, K.: Global mercury emissions to the atmosphere from anthropogenic and natural sources, Atmos. Chem. Phys., 10, 5951-5964, doi:10.5194/acp-10-59512010, 2010.

Poissant, L., Pilote, M., Beauvais, C., Constant, P., and Zhang, H. H.: A year of continuous measurements of three atmospheric mercury species (GEM, RGM and $\mathrm{Hg}-\mathrm{p}$ ) in southern Quebec, Canada, Atmos. Environ., 39, 1275-1287, doi:10.1016/j.atmosenv.2004.11.007, 2005.

Prestbo, E. and Gay, D. A.: Wet deposition of mercury in the U.S. and Canada, 1996-2005: Results and analysis of the NADP mercury deposition network (MDN), Atmos. Environ., 43, 4223=4233, 2009.

Rea, A. W., Lindberg, S. E., and Keeler, G. J.: Dry deposition and foliar leaching of mercury and selected trace elements in deciduous forest throughfall, Atmos. Environ., 35, 3453-3462, doi:10.1016/S1352-2310(01)00133-9, 2001.

Ren, W., Duan, L., Zhu, Z. W., Du, W., An, Z. Y., Xu, L. J., Zhang, C., Zhuo, Y. Q., and Chen, C. H.: Mercury Transformation and Distribution Across a Polyvinyl Chloride (PVC) Production Line in China, Environ. Sci. Technol., 48, 2321-2327, doi:10.1021/Es404147c, 2014.

Savage, N. H., Law, K. S., Pyle, J. A., Richter, A., Nüß, H., and Burrows, J. P.: Using GOME $\mathrm{NO}_{2}$ satellite data to examine regional differences in TOMCAT model performance, Atmos. Chem. Phys., 4, 1895-1912, doi:10.5194/acp-4-1895-2004, 2004.

Schleicher, N. J., Schafer, J., Blanc, G., Chen, Y., Chai, F., Cen, K., and Norra, S.: Atmospheric particulate mercury in the megacity Beijing: Spatiotemporal variations and source apportionment, Atmos. Environ., 109, 251-261, doi:10.1016/j.atmosenv.2015.03.018, 2015.

Schroeder, W. H. and Munthe, J.: Atmospheric mercury - An overview, Atmos. Environ., 32, 809-822, doi:10.1016/S13522310(97)00293-8, 1998.

Schroeder, W. H., Anlauf, K. G., Barrie, L. A., Lu, J. Y., Steffen, A., Schneeberger, D. R., and Berg, T.: Arctic springtime depletion of mercury, Nature, 394, 331-332, doi:10.1038/28530, 1998.

Schwesig, D. and Matzner, E.: Pools and fluxes of mercury and methylmercury in two forested catchments in Germany, Sci. Total Environ., 260, 213-223, doi:10.1016/S0048-9697(00)005659, 2000.

Seigneur, C., Vijayaraghavan, K., Lohman, K., Karamchandani, P., and Scott, C.: Global source attribution for mercury deposition in the United States, Environ. Sci. Technol., 38, 555-569, doi:10.1021/Es034109t, 2004.

Selin, N. E., Jacob, D. J., Park, R. J., Yantosca, R. M., Strode, S., Jaegle, L., and Jaffe, D.: Chemical cycling and deposition of atmospheric mercury: Global constraints from observations, J. Geophys. Res.-Atmos., 112, D02308, doi:10.1029/2006jd007450, 2007.

Shetty, S. K., Lin, C. J., Streets, D. G., and Jang, C.: Model estimate of mercury emission from natural sources in East Asia, Atmos. Environ., 42, 8674-8685, doi:10.1016/j.atmosenv.2008.08.026, 2008.

Sheu, G. R. and Mason, R. P.: An examination of methods for the measurements of reactive gaseous mercury in the atmosphere, Environ. Sci. Technol., 35, 1209-1216, doi:10.1021/Es001183s, 2001.

Sheu, G. R., Lin, N. H., Wang, J. L., Lee, C. T., Yang, C. F. O., and Wang, S. H.: Temporal distribution and potential sources of atmospheric mercury measured at a high-elevation background station in Taiwan, Atmos. Environ., 44, 2393-2400, doi:10.1016/j.atmosenv.2010.04.009, 2010.

Sheu, G. R., Lin, N. H., Lee, C. T., Wang, J. L., Chuang, M. T., Wang, S. H., Chi, K. H., and Ou-Yang, C. F.: Distribution of atmospheric mercury in northern Southeast Asia and South China Sea during Dongsha Experiment, Atmos. Environ., 78, 174-183, doi:10.1016/j.atmosenv.2012.07.002, 2013.

Slemr, F. and Scheel, H. E.: Trends in atmospheric mercury concentrations at the summit of the Wank mountain, southern Germany, Atmos. Environ., 32, 845-853, doi:10.1016/S13522310(97)00131-3, 1998.

Slemr, F., Brunke, E. G., Ebinghaus, R., Temme, C., Munthe, J., Wangberg, I., Schroeder, W., Steffen, A., and Berg, T.: Worldwide trend of atmospheric mercury since 1977, Geophys. Res. Lett., 30, 1516, doi:10.1029/2003g1016954, 2003.

Slemr, F., Ebinghaus, R., Brenninkmeijer, C. A. M., Hermann, M., Kock, H. H., Martinsson, B. G., Schuck, T., Sprung, D., van Velthoven, P., Zahn, A., and Ziereis, H.: Gaseous mercury distribution in the upper troposphere and lower stratosphere observed onboard the CARIBIC passenger aircraft, Atmos. Chem. Phys., 9, 1957-1969, doi:10.5194/acp-9-1957-2009, 2009.

Slemr, F., Brunke, E.-G., Ebinghaus, R., and Kuss, J.: Worldwide trend of atmospheric mercury since 1995, Atmos. Chem. Phys., 11, 4779-4787, doi::0.5194/acp-11-4779-2011, 2011.

Slemr, F., Weigelt, A., Ebinghaus, R., Brenninkmeijer, C., Baker, A., Schuck, T., Rauthe-Schoch, A., Riede, H., Leedham, E., Hermann, M., van Velthoven, P., Oram, D., O'Sullivan, D., Dyroff, C., Zahn, A., and Ziereis, H.: Mercury Plumes in the Global Upper Troposphere Observed during Flights with the CARIBIC Observatory from May 2005 until June 2013, Atmosphere-Basel, 5, 342-369, doi:10.3390/Atmos5020342, 2014.

Slemr, F., Angot, H., Dommergue, A., Magand, O., Barret, M., Weigelt, A., Ebinghaus, R., Brunke, E.-G., Pfaffhuber, K. A., Edwards, G., Howard, D., Powell, J., Keywood, M., and Wang, F.: Comparison of mercury concentrations measured at several sites in the Southern Hemisphere, Atmos. Chem. Phys., 15, 31253133, doi:10.5194/acp-15-3125-2015, 2015.

Song, S., Selin, N. E., Soerensen, A. L., Angot, H., Artz, R., Brooks, S., Brunke, E.-G., Conley, G., Dommergue, A., Ebinghaus, R., Holsen, T. M., Jaffe, D. A., Kang, S., Kelley, P., Luke, W. T., Magand, O., Marumoto, K., Pfaffhuber, K. A., Ren, X., Sheu, G.-R., Slemr, F., Warneke, T., Weigelt, A., Weiss-Penzias, P., Wip, D. C., and Zhang, Q.: Top-down constraints on atmospheric mercury emissions and implications for global biogeochemical cycling, Atmos. Chem. Phys., 15, 7103-7125, doi:10.5194/acp-157103-2015, 2015. 
Song, X. J., Cheng, I., and Lu, J.: Annual atmospheric mercury species in Downtown Toronto, Canada, J. Environ. Monitor., 11, 660-669, doi:10.1039/B815435j, 2009.

Sprovieri, F. and Pirrone, N.: Spatial and temporal distribution of atmospheric mercury species over the Adriatic Sea, Environ. Fluid. Mech., 8, 117-128, doi:10.1007/s10652-007-9045-4, 2008.

Sprovieri, F., Pirrone, N., Landis, M. S., and Stevens, R. K.: Oxidation of gaseous elemental mercury to gaseous divalent mercury during 2003 polar sunrise at Ny-Alesund, Environ. Sci. Technol., 39, 9156-9165, doi:10.1021/Es050965o, 2005.

St Louis, V. L., Rudd, J. W. M., Kelly, C. A., Hall, B. D., Rolfhus, K. R., Scott, K. J., Lindberg, S. E., and Dong, W.: Importance of the forest canopy to fluxes of methyl mercury and total mercury to boreal ecosystems, Environ. Sci. Technol., 35, 3089-3098, doi:10.1021/Es001924p, 2001.

Streets, D. G., Yarber, K. F., Woo, J. H., and Carmichael, G. R.: Biomass burning in Asia: Annual and seasonal estimates and atmospheric emissions, Global Biogeochem. Cy., 17, 1099, doi:10.1029/2003gb002040, 2003.

Streets, D. G., Hao, J. M., Wu, Y., Jiang, J. K., Chan, M., Tian, H. Z., and Feng, X. B.: Anthropogenic mercury emissions in China, Atmos. Environ., 39, 7789-7806, doi:10.1016/j.atmosenv.2005.08.029, 2005.

Streets, D. G., Devane, M. K., Lu, Z. F., Bond, T. C., Sunderland, E. M., and Jacob, D. J.: All-Time Releases of Mercury to the Atmosphere from Human Activities, Environ. Sci. Technol., 45, 10485-10491, doi:10.1021/Es202765m, 2011.

Strode, S. A., Jaegle, L., Jaffe, D. A., Swartzendruber, P. C., Selin, N. E., Holmes, C., and Yantosca, R. M.: Trans-Pacific transport of mercury, J. Geophys. Res.-Atmos., 113, D15305, doi:10.1029/2007jd009428, 2008.

Su, J., Cheng, J. P., Ye, X. F., Yuan, T., Wang, W. H., and Mi, L. $\mathrm{J}$ : Preliminary study on mercury distribution in multimedia environment in Lanzhou, J. Agro-Environ. Sci., 26, 381-385, 2007 (in Chinese).

Swartzendruber, P. C., Jaffe, D. A., Prestbo, E. M., Weiss-Penzias, P., Selin, N. E., Park, R., Jacob, D. J., Strode, S., and Jaegle, L.: Observations of reactive gaseous mercury in the free troposphere at the Mount Bachelor Observatory, J. Geophys. Res.-Atmos., 111, D24302, doi:10.1029/2006jd007415, 2006.

Swartzendruber, P. C., Chand, D., Jaffe, D. A., Smith, J., Reidmiller, D., Gratz, L., Keeler, J., Strode, S., Jaegle, L., and Talbot, R.: Vertical distribution of mercury, CO, ozone, and aerosol scattering coefficient in the Pacific Northwest during the spring 2006 INTEX-B campaign, J. Geophys. Res.-Atmos., 113, D10305, doi:10.1029/2007jd009579, 2008.

Talbot, R., Mao, H., Scheuer, E., Dibb, J., and Avery, M.: Total depletion of $\mathrm{Hg}$ degrees in the upper tropospherelower stratosphere, Geophys. Res. Lett., 34, L23804, doi:10.1029/2007g1031366, 2007.

Temme, C., Slemr, F., Ebinghaus, R., and Einax, J. W.: Distribution of mercury over the Atlantic Ocean in 1996 and 19992001, Atmos. Environ., 37, 1889-1897, doi:10.1016/S13522310(03)00069-4, 2003.

Timonen, H., Ambrose, J. L., and Jaffe, D. A.: Oxidation of elemental $\mathrm{Hg}$ in anthropogenic and marine airmasses, Atmos. Chem. Phys., 13, 2827-2836, doi:10.5194/acp-13-2827-2013, 2013.

Tohjima, Y., Kubo, M., Minejima, C., Mukai, H., Tanimoto, H., Ganshin, A., Maksyutov, S., Katsumata, K., Machida, T., and
Kita, K.: Temporal changes in the emissions of $\mathrm{CH}_{4}$ and $\mathrm{CO}$ from China estimated from $\mathrm{CH}_{4} / \mathrm{CO}_{2}$ and $\mathrm{CO} / \mathrm{CO}_{2}$ correlations observed at Hateruma Island, Atmos. Chem. Phys., 14, 1663-1677, doi:10.5194/acp-14-1663-2014, 2014.

van Donkelaar, A., Martin, R. V., Brauer, M., Kahn, R., Levy, R., Verduzco, C., and Villeneuve, P. J.: Global Estimates of Ambient Fine Particulate Matter Concentrations from Satellite-Based Aerosol Optical Depth: Development and Application, Environ. Health Persp., 118, 847-855, doi:10.1289/Ehp.0901623, 2010.

Wan, Q., Feng, X. B., Lu, J., Zheng, W., Song, X. J., Li, P., Han, S. J., and $\mathrm{Xu}, \mathrm{H}$. : Atmospheric mercury in Changbai Mountain area, northeastern China II. The distribution of reactive gaseous mercury and particulate mercury and mercury deposition fluxes, Environ. Res., 109, 721-727, doi:10.1016/j.envres.2009.05.006, 2009a.

Wan, Q., Feng, X. B., Lu, J. L., Zheng, W., Song, X. J., Han, S. J., and $\mathrm{Xu}, \mathrm{H} .:$ Atmospheric mercury in Changbai Mountain area, northeastern China I. The seasonal distribution pattern of total gaseous mercury and its potential sources, Environ Res, 109, 201-206, DOI 10.1016/j.envres.2008.12.001, 2009b.

Wang, D. Y., He, L., Shi, X. J., Wei, S. Q., and Feng, X. B.: Release flux of mercury from different environmental surfaces in Chongqing, China, Chemosphere, 64, 1845-1854, doi:10.1016/j.chemosphere.2006.01.054, 2006.

Wang, L., Wang, S. X., Zhang, L., Wang, Y. X., Zhang, Y. X., Nielsen, C., McElroy, M. B., and Hao, J. M.: Source apportionment of atmospheric mercury pollution in China using the GEOS-Chem model, Environ. Pollut., 190, 166-175, doi:10.1016/j.envpol.2014.03.011, 2014.

Wang, S. X., Zhang, L., Wang, L., Wu, Q. R., Wang, F. Y., and Hao, J. M.: A review of atmospheric mercury emissions, pollution and control in China, Front. Env. Sci. Eng., 8, 631-649, doi:10.1007/s11783-014-0673-x, 2014.

Wang, Y. M., Wang, D. Y., Meng, B., Peng, Y. L., Zhao, L., and Zhu, J. S.: Spatial and temporal distributions of total and methyl mercury in precipitation in core urban areas, Chongqing, China, Atmos. Chem. Phys., 12, 9417-9426, doi:10.5194/acp-12-94172012, 2012.

Wang, Y. M., Peng, Y. L., Wang, D. Y., and Zhang, C.: Wet deposition fluxes of total mercury and methylmercury in core urban areas, Chongqing, China, Atmos. Environ., 92, 87-96, doi:10.1016/j.atmosenv.2014.03.059, 2014.

Wang, Z. W., Zhang, X. S., Chen, Z. S., and Zhang, Y.: Mercury concentrations in size-fractionated airborne particles at urban and suburban sites in Beijing, China, Atmos. Environ., 40, 2194 2201, doi:10.1016/j.atmosenv.2005.12.003, 2006.

Wang, Z. W., Chen, Z. S., Duan, N., and Zhang, X. S.: Gaseous elemental mercury concentration in atmosphere at urban and remote sites in China, J. Environ. Sci.-China, 19, 176-180, doi:10.1016/S1001-0742(07)60028-X, 2007.

Wang, Z. W., Zhang, X. S., Xiao, J. S., Zhijia, C., and Yu, P. Z.: Mercury fluxes and pools in three subtropical forested catchments, southwest China, Environ. Pollut., 157, 801-808, doi:10.1016/j.envpol.2008.11.018, 2009.

Wangberg, I., Schmolke, S., Schager, P., Munthe, J., Ebinghaus, R., and Iverfeldt, A.: Estimates of air-sea exchange of mercury in the Baltic Sea, Atmos. Environ., 35, 5477-5484, doi:10.1016/S1352-2310(01)00246-1, 2001. 
Wangberg, I., Munthe, J., Berg, T., Ebinghaus, R., Kock, H. H., Temme, C., Bieber, E., Spain, T. G., and Stolk, A.: Trends in air concentration and deposition of mercury in the coastal environment of the North Sea Area, Atmos. Environ., 41, 2612-2619, doi:10.1016/j.atmosenv.2006.11.024, 2007.

Weiss-Penzias, P., Jaffe, D. A., Swartzendruber, P., Dennison, J. B., Chand, D., Hafner, W., and Prestbo, E.: Observations of Asian air pollution in the free troposphere at Mount Bachelor Observatory during the spring of 2004, J. Geophys. Res.-Atmos., 111, D10304, doi:10.1029/2005jd006522, 2006.

Weiss-Penzias, P., Jaffe, D., Swartzendruber, P., Hafner, W., Chand, D., and Prestbo, E.: Quantifying Asian and biomass burning sources of mercury using the $\mathrm{Hg} / \mathrm{CO}$ ratio in pollution plumes observed at the Mount Bachelor Observatory, Atmos. Environ., 41, 4366-4379, doi:10.1016/j.atmosenv.2007.01.058, 2007.

Wu, P. P.: Studies on temporal and spatial distributions of atmospheric mercury in Taiwan Strait inshore areas, Master's dissertation, Xiamen Universitry, Xiamen, China, 102 pp., 2014 (in Chinese).

Wu, Y., Wang, S. X., Streets, D. G., Hao, J. M., Chan, M., and Jiang, J. K.: Trends in anthropogenic mercury emissions in China from 1995 to 2003, Environ. Sci. Technol., 40, 5312-5318, doi:10.1021/Es060406x, 2006.

Xia, C. H., Xie, Z. Q., and Sun, L. G.: Atmospheric mercury in the marine boundary layer along a cruise path from Shanghai, China to Prydz Bay, Antarctica, Atmos. Environ., 44, 18151821, doi:10.1016/j.atmosenv.2009.12.039, 2010.

Xiang, J. Q. and Liu, G. J.: Distribution and sources of atmospheric mercury in urban areas of Wuhan, Resour. Environ. Eng., 22, 2730, 2008 (in Chinese).

Xiu, G. L., Cai, J., Zhang, W. Y., Zhang, D. N., Bueler, A., Lee, S. C., Shen, Y., Xu, L. H., Huang, X. J., and Zhang, P.: Speciated mercury in size-fractionated particles in Shanghai ambient air, Atmos. Environ., 43, 3145-3154, doi:10.1016/j.atmosenv.2008.07.044, 2009.

Xiu, G. L. L., Jin, Q. X., Zhang, D. N., Shi, S. Y., Huang, X. J., Zhang, W. Y., Bao, L., Gao, P. T., and Chen, B.: Characterization of size-fractionated particulate mercury in Shanghai ambient air, Atmos. Environ., 39, 419-427, doi:10.1016/j.atmosenv.2004.09.046, 2005.

Xu, L. L., Chen, J. S., Niu, Z. C., Yin, L. Q., and Chen, Y. T.: Characterization of mercury in atmospheric particulate matter in the southeast coastal cities of China, Atmos. Pollut. Res., 4, 454461, doi:10.5094/Apr.2013.052, 2013.

Xu, L. L., Chen, J. S., Yang, L. M., Niu, Z. C., Tong, L., Yin, L. Q., and Chen, Y. T.: Characteristics and sources of atmospheric mercury speciation in a coastal city, Xiamen, China, Chemosphere, 119, 530-539, 2015.

Yang, Y. K., Chen, H., and Wang, D. Y.: Spatial and temporal distribution of gaseous elemental mercury in Chongqing, China, Environ. Monit. Assess., 156, 479-489, doi:10.1007/s10661-0080499-8, 2009.

Yu, B., Wang, X., Lin, C. J., Fu, X. W., Zhang, H., Shang, L. H., and Feng, X. B.: Atmospheric mercury; Speciation; Pollutant transport; Potential Source Contribution Function; Monsoon; Air quality index, J. Geophys. Res.-Atmos., 120, doi:10.1002/2015JD023425, 2015.
Zhang, H., Fu, X. W., Lin, C.-J., Wang, X., and Feng, X. B.: Observation and analysis of speciated atmospheric mercury in ShangriLa, Tibetan Plateau, China, Atmos. Chem. Phys., 15, 653-665, doi::10.5194/acp-15-653-2015, 2015a.

Zhang, H., Fu, X. W., Lin, C. J., Wang, X., Feng, X. B., Yu, B., Zhou, J., and Zhang, Y. P.: Impacts of Indian summer monsoon on distribution of atmospheric mercury at a high-altitude background station, southwestern China, under preparation, 2015b.

Zhang, L., Blanchard, P., Gay, D. A., Prestbo, E. M., Risch, M. R., Johnson, D., Narayan, J., Zsolway, R., Holsen, T. M., Miller, E. K., Castro, M. S., Graydon, J. A., Louis, V. L. St., and Dalziel, J.: Estimation of speciated and total mercury dry deposition at monitoring locations in eastern and central North America, Atmos. Chem. Phys., 12, 4327-4340, doi:10.5194/acp-12-43272012, 2012.

Zhang, L., Wang, S. X., Wang, L., and Hao, J. M.: Atmospheric mercury concentration and chemical speciation at a rural site in Beijing, China: implications of mercury emission sources, Atmos. Chem. Phys., 13, 10505-10516, doi:10.5194/acp-1310505-2013, 2013.

Zhang, L., Wang, S. X., Wang, L., Wu, Y., Duan, L., Wu, Q. R., Wang, F. Y., Yang, M., Yang, H., Hao, J. M., and Liu, X.: Updated Emission Inventories for Speciated Atmospheric Mercury from Anthropogenic Sources in China, Environ. Sci. Technol., 49, 3185-3194, doi:10.1021/Es504840m, 2015.

Zhang, L. M., Gong, S. L., Padro, J., and Barrie, L.: A size-segregated particle dry deposition scheme for an atmospheric aerosol module, Atmos. Environ., 35, 549-560, doi:10.1016/S1352-2310(00)00326-5, 2001.

Zhang, L. M., Wright, L. P., and Blanchard, P.: A review of current knowledge concerning dry deposition of atmospheric mercury, Atmos. Environ., 43, 5853-5864, doi:10.1016/j.atmosenv.2009.08.019, 2009.

Zhang, Y. Q., Liu, R. H., Cui, Y. Q., Zhou, J. P., and Wang, Y.: The characteristic analysis of atmospheric mercury during haze days in Qingdao, Chinese Environ. Sci., 34, 1905-1911, 2014 (in Chinese).

Zhou, J., Feng, X. B., Liu, H. Y., Zhang, H., Fu, X. W., Bao, Z. D., Wang, X., and Zhang, Y. P.: Examination of total mercury inputs by precipitation and litterfall in a remote upland forest of Southwestern China, Atmos. Environ., 81, 364-372, doi:10.1016/j.atmosenv.2013.09.010, 2013.

Zhu, J., Wang, T., Talbot, R., Mao, H., Hall, C. B., Yang, X., Fu, C., Zhuang, B., Li, S., Han, Y., and Huang, X.: Characteristics of atmospheric Total Gaseous Mercury (TGM) observed in urban Nanjing, China, Atmos. Chem. Phys., 12, 12103-12118, doi:10.5194/acp-12-12103-2012, 2012.

Zhu, J., Wang, T., Talbot, R., Mao, H., Yang, X., Fu, C., Sun, J., Zhuang, B., Li, S., Han, Y., and Xie, M.: Characteristics of atmospheric mercury deposition and size-fractionated particulate mercury in urban Nanjing, China, Atmos. Chem. Phys., 14, 2233 2244, doi:10.5194/acp-14-2233-2014, 2014. 